Zabytkoznawstwo i Konserwatorstwo XL, Toruń 2011

Anna Frąckowska, Jacek Tylicki

\title{
Bröllmannowie - złotnicy toruńscy przełomu XVII i XVIII wieku. Addenda i corrigenda
}

$\mathrm{O}$ d momentu publikacji monograficznego artykułu poświęconego złotnikom z rodziny Bröllmannów upłynęło już ponad piętnaście lat ${ }^{1}$. W tym okresie można zaobserwować wyraźną intensyfikację badań nad złotnictwem i rzemiosłem artystycznym na terenie Polski, zwłaszcza na obszarze dawnych Prus Królewskich. Ukazało się wiele artykułów, opracowano obszerne katalogi najważniejszych kolekcji złotnictwa, w ostatnich latach zorganizowano także kilkanaście ważnych wystaw, prezentujących zabytki z muzealnych, kościelnych oraz prywatnych zbiorów tego rzemiosła; pokazom towarzyszyły zwykle okazałe wydawnictwa. Istotnym źródłem informacji stały się również dane z rynku antykwarycznego, łatwo dostępne przede wszystkim dzięki coraz liczniejszym publikacjom elektronicznym.

Prowadzone badania, kwerendy oraz dostęp do nowych źródeł informacji zaowocowały ujawnieniem grupy kolejnych zabytków autorstwa Niklausa i Johanna Christiana Bröllmannów, zarówno w kolekcjach różnego typu, jak i na rynku antykwarycznym. Dzięki studiom historycznym natomiast odkryte zostały nowe, interesujące informacje biograficzne dotyczące rodziny toruńskich złotników. Wydaje się zatem, że nadszedł czas na zebranie w jednym miejscu i podsumowanie tych rozproszonych informacji oraz rozszerzenie katalogu prac

1 J. Tylicki, Bröllmannowie, złotnicy toruńscy przełomu XVII i XVIII w., „Acta Universitas Nicolai Copernici. Zabytkoznawstwo i Konserwatorstwo" 1992, z. XVI, s. 91-128 (cz. I); 1994, z. XIX, s. 55-100 (cz. II: katalog). 
Bröllmannów o następne przedmioty, a także uzupełnienie go o nowe ustalenia dotyczące znanych dzieł².

Działalność Bröllmannów nie była we wspomnianym czasie przedmiotem osobnych studiów. Wiele natomiast nowych informacji biograficznych udało się uzyskać przy okazji szerszych badań historyków nad mieszczaństwem i patrycjatem toruńskim XVII i XVIII wieku. Szczególnie owocne okazały się poszukiwania archiwalne (w toruńskich aktach miejskich, a także w księgach parafialnych i innych dokumentach kościelnych, czy też w materiałach dotyczących toruńskiego Gimnazjum Akademickiego). Na temat samych Bröllmannów powstały trzy kolejne publikacje słownikowe, w których uwzględniono częściowo te nowe dane. Są to noty biograficzne autorstwa Michała Woźniaka ${ }^{3}$ oraz dwie kolejne w opracowaniu Janusza Tandeckiego - niemieckoi polskojęzyczna ${ }^{4}$.

Na podstawie archiwaliów dowiadujemy się, że Niklaus był synem Samuela ${ }^{5}$. Niestety, jego pochodzenie i data urodzin nadal pozostają zagadką. Wymienieni autorzy najnowszych biogramów (zgadzając się z wcześniejszymi sugestiami $\left.{ }^{6}\right)$ podają, że przyszły złotnik przybył prawdopodobnie z północnych Niemiec i jako datę jego urodzenia przyjmują czas około 1640 roku. Wiadomo także, że starszy Bröllmann już jako mistrz posiadał dom na Starym Mieście, przy ulicy Chełmińskiej (numer domu 337) ${ }^{7}$ oraz był członkiem III Ordynku, powołanym przed

2 Za zachętę i mobilizację do podjęcia tej pracy, a przede wszystkim za udostępnienie szeregu informacji i materiałów, autorzy serdecznie dziękują panu Dariuszowi Nowackiemu z Zamku Królewskiego na Wawelu.

3 Bröllmannowie, oprac. M. Woźniak, w: Słownik Biograficzny Pomorza Nadwiślańskiego, t. I: A-F, red. S. Gierszewski, Gdańsk 1992, s. 165-167.

4 J. Tandecki, Bröllmann (Johann Christian, Nikolaus, Samuel), w: Saur Algemeines Künstler-Lexikon. Die Bildenden Künstler aller Zeiten und Völker. Band 14, München-Leipzig 1996, s. 329-330; Nikolaus Bröllmann, Johann Christian Bröllmann, Samuel Bröllmann, oprac. J. Tandecki, w: Toruński Słownik Biograficzny. red. K. Mikulski, Toruń 1998, t. I, s. 43-44.

5 Nikolaus Bröllmann, Johann Christian Bröllmann, Samuel Bröllmann, oprac. J. Tandecki, s. 43 (autor nie przytacza dokładnego źródła tej informacji).

6 J. Tylicki, Bröllmannowie, cz. I, s. 119.

7 Nikolaus Bröllmann, Johann Christian Bröllmann, Samuel Bröllmann, oprac. J. Tandecki, s. 44. 
5 kwietnia $1690 \mathrm{roku}^{8}$. Najciekawsza informacja z biografii Bröllmanna seniora dotyczy jednak jego powtórnego ożenku. Po śmierci pierwszej żony, Katarzyny Kohl, co nastąpiło prawdopodobnie w niedługi czas po ślubie (najpewniej w 1673 roku $^{9}$ ), zawarł on ponownie związek małżeński z Anną Chodowieckąa ${ }^{10}$, która urodziła mu dwóch synów, znanych już wcześniej z literatury: Johanna Christiana i Samuela.

Wszystko wskazuje na to, że druga żona Niklausa należała do rodziny Chodowieckich, pochodzącej $\mathrm{z}$ Wielkopolski, a w drugiej połowie XVII wieku osiadłej również w Gdańsku, z której wywodził się Daniel Chodowiecki. Bliskie związki obu rodów potwierdza także drobny fakt z biografii znanego malarza i rytownika. Po wczesnej śmierci ojca, w 1740 roku, kilkunastoletni Daniel praktykował jako uczeń kupiecki w sklepie kolonialnym swojej ciotki, wdowy o nazwisku Bröllmann ${ }^{11}$. Fakty te dowodzą, że Bröllmannowie mieli silne powiązania z Gdańskiem na gruncie rodzinnym, co zapewne zaowocowało także kontaktami w środowisku złotniczym tego miasta i mogło mieć znaczący wpływ na ich działalność artystyczną, chociażby przez znajo-

8 J. Dygdała, Urzędnicy miejscy Torunia: spisy. Cz. III: 1651-1793, Toruń 2002, s. 158 , nr 703.

9 Niklaus poślubił Katarzynę 17 maja 1672 r., natomiast Johann Christian, syn Anny urodził się na początku 1675 r. - Archiwum Parafii NMP w Toruniu, T.[rauungs] R.[erister] 1600-1756 [Staromiejska Gmina Ewangelicka w Toruniu], s. 198; Tauffbuch Der Kirchen zu SMarien in Thorun gehörig Anno 1616. Verehret Johann Wedemeyer der Elter [1616-1676], s. 388.

10 Nikolaus Bröllmann, Johann Christian Bröllmann, Samuel Bröllmann, oprac. J. Tandecki. Zapewne była ona spokrewniona z Janem Samuelem Chodowieckim, mieszczaninem i kupcem toruńskim osiadłym w mieście co najmniej od lat 40 . XVII w. W zbiorach archiwalnych zachowały się listy Jan Samuela Chodowieckiego z Torunia z lat 1646-1647 i 1663-1673. (Archiwum Państwowe w Poznaniu, Akta Braci Czeskich 1557-1817, zespół 892, sygn. 102, 731 (mikrofilm nr 076685. 1663, 1667, 1670, 1673. 5 listów; 077314). Korzystano z publikacji Wielkopolskiej Biblioteki Cyfrowej: oai:www. wbc.poznan.pl:54214 (22.04.2009).

11 W. von Oettingen, Daniel Chodowiecki: ein Berliner Künstlerleben im achtzehnten Jahrhundert, Berlin 1895, s. 15; P. Landau, Daniel Chodowiecki: ein kulturgeschichtliches Lebensbild, Berlin 1923, s. 5-6. Niestety w żadnym z licznych opracowań nie zostało podane imię wspominanej kobiety ani sprecyzowany stopień pokrewieństwa. Co więcej, w kilku publikacjach powtarza się wzmianka, że osoba ta należała do rodziny matki rysownika. E. Hinrichs, K. Zernack, Daniel Chodowiecki (1726-1801), Kupferstecher, Illustrator, Kaufmann, Tübingen 1997, s. 37. 
mość aktualnej gdańskiej wytwórczości, pozyskiwanie wzorników, czy półfabrykatów do produkcji złotniczej, np. odlewów.

Inną ciekawą sprawą jest strona religijno-obyczajowa wspomnianego małżeństwa. Chodowieccy należeli bowiem do wspólnoty Braci Czeskich (ruchu religijnego wyrosłego z XV-wiecznego husytyzmu, który po pojawieniu się reformacji przyjął część poglądów protestantów), Bröllmannowie natomiast byli kalwinistami ${ }^{12}$. Wyznania te, zachowując formalną odrębność, reprezentowały bardzo podobną doktrynę religijną i często blisko ze sobą współistniały, co w końcu przyniosło faktyczną unię $e^{13}$.

Z Anną, małżonką starszego złotnika wiązać można $\mathrm{z}$ dużym prawdopodobieństwem inną jeszcze intrygującą wzmiankę: około 1706 roku żona Mikołaja Brillmana ufundowała krzyż na ołtarz w zakrystii do protestanckiego kościoła św. Jerzego w Toruniu, odbudowywanego i na nowo wyposażanego po zniszczeniach w 1703 $\mathrm{roku}^{14}$. Mowa tu prawdopodobnie o dziele złotniczym, a więc byłby to przypuszczalnie ślad kolejnego przedmiotu, pochodzącego z warsztatu Bröllmannów (o którym brak jednak dalszych informacji).

Warto przytoczyć także nowe fakty z życia Johanna Christiana. Nie odziedziczył on warsztatu po ojcu, ale jeszcze za jego życia założył

12 K. Mikulski, Pułapka niemożności. Społeczeństwo nowoczesnego miasta wobec procesów modernizacyjnych (na przykładzie Torunia w XVII i XVIII wieku), Toruń 2004, s. 136-137.

13 Między obu wyznaniami istniały początkowo różnice teologiczne, dotyczące Wieczerzy Pańskiej, jednak te dwie konfesje już od połowy XVI w. współdziałały ze sobą, a Jednota Czeska zaczęła się coraz bardziej doktrynalnie upodabniać do kalwinizmu. Odbyło się kilka wspólnych synodów: w Kuźmiaku (1555 r.), we Włodawie (1634 r.) i Orli (1644 r.). Co prawda nigdy nie dokonano formalnego aktu scalenia, ale ustanawiano daleko posuniętą zgodność nauczania i ścisłą współpracę. Wspólnoty uznawały nawzajem swoich duchownych i sakramenty, a od drugiej połowy XVII w. tworzyły najczęściej jeden zbór, tak że ostatecznie o ich odmienności stanowiła tylko nazwa. Dla zaznaczenia innego rodowodu czasem mówiono jedynie o zborze reformowanym „w tradycji Braci Czeskich”. Szerzej na ten temat m.in. H. Gmitrek, Bracia czescy a kalwini w Rzeczypospolitej: połowa XVI-połowa XVII wieku: studium porównawcze, Lublin 1987; J. Dworzaczkowa, Bracia czescy w Wielkopolsce w XVI i XVII wieku, Warszawa 1997.

14 P. Birecki, Sztuka luterańska na ziemi chełmińskiej od drugiej połowy XVI do pierwszej ćwierci XVIII wieku, Warszawa 2007, s. 111. 
własny ${ }^{15}$. Wiadomo, że był członkiem III Ordynku, do którego wybrano go 17 marca 1706 roku $^{16}$. W latach 1706-1709 mieszkał w kamienicy przy ulicy Chełmińskiej (dom nr 343) a w 1710 roku kupił inny dom przy tej ulicy, o numerze 306. Żoną złotnika była Elisabeth z domu Hemling ${ }^{17}$. Ich synami byli przypuszczalnie dwaj uczniowie toruńskiego Gimnazjum Akademickiego: Johann Christian Brülmann, syn złotnika, przyjęty do szkoły w 1711 roku, oraz David Henrich Brölmann, zapisany $\mathrm{w} 1721 \mathrm{roku}^{18}$. Nic nie wiadomo o tym, aby którykolwiek z nich kontynuował zawód ojca. Johann Christian sprawował również funkcję jednego z przełożonych (Vorsteher) toruńskiej wspólnoty kościoła reformowanego (kalwińskiego). Zachowały się dokumenty gminy tego kościoła z lat 1710-1720, na których widnieje podpis złotnika (il. 1). Dotyczą one m.in. śmierci pastora Tobiana (1710 r.), czy też prośby o wsparcie finansowe gminy, skierowanej do biskupa anglikańskiego Robbinsona, przebywającego w holenderskim Utrechcie (1713 r.). Mistrz zapisywał na nich swoje nazwisko w bardzo zróżnicowanym brzmieniu $^{19}$. Udało się także ustalić pewną datę jego śmierci - 27 lutego $1732 \mathrm{roku}^{20}$.

15 K. Mikulski, Pułapka niemożności, s. 136.

16 J. Dygdała, Urzędnicy miejscy Torunia, s. 168, nr 808.

17 K. Mikulski, Pułapka niemożności, s. 136-137 (tam odwołanie do źródeł archiwalnych). Pośród mieszczan toruńskich odnotowani są czterej urzędnicy miejscy o tym nazwisku. Elisabeth najprawdopodobniej była córką Johanna Hemmlinga (juniora) - kupca, członka III Ordynku w latach 1690-1696, ławnika Starego Miasta 1696-1712, lub Hansa, piekarza, członka III Ordynku w latach 1690-1703; J. Dygdała, Urzędnicy miejscy Torunia, s. 159-160, nr 715, 721.

18 Z. H. Nowak, J. Tandecki, Metryka uczniów Toruńskiego Gimnazjum Akademickiego 1600-1817. Część pierwsza (1600-1717), Toruń 1997; Część druga (1718-1817), Toruń 1998, nr 8366, 8743. Pisownia nazwisk za tekstem publikacji. Na nazwisko Johanna Christiana juniora nie zwrócono do tej pory uwagi. Drugiego ucznia, jako prawdopodobnego syna Johanna Christiana, wspomina Tandecki, Nikolaus Bröllmann, Johann Christian Bröllmann, Samuel Bröllmann, oprac. J. Tandecki, s. 43.

19 Listy Gminy kościoła reformowanego w Toruniu do Dawida Cassiusa [superintendent kościoła reformowanego w Lesznie] 1718-1720. Archiwum Państwowe w Poznaniu, Akta Braci Czeskich 1557-1817, zespół 892, sygn. 329, 800, 1854. korzystano z publikacji Wielkopolskiej Biblioteki Cyfrowej: www.wbc.poznan.pl/dlibra/ docconnect?id=54572 (23.04.2009).

20 Badacze podają różne przybliżone daty, powołując się na najpóźniejsze znane im archiwalne wzmianki o złotniku: Tandecki - po 18 maja 1731 roku; Woźniak 
Nieco informacji zyskujemy także na temat młodszego syna Niklausa, Samuela. Został on ochrzczony 15 sierpnia 1684 roku, zmarł natomiast 13 października 1738 roku $^{21}$. Przed uzyskaniem mistrzostwa działał (w latach 1703-1711) w warsztacie rodzinnym kierowanym przez matkę, który następnie przejął i prowadził do 1723 roku. W latach 1723-1724 mieszkał $\mathrm{w}$ domu sąsiadującym $\mathrm{z}$ rodzicielskim przy ulicy Chełmińskiej (numer 336), na który zamienił się z Jakubem Weintraubem. Sytuacja ekonomiczna młodszego z braci była, jak można sądzić, bardzo zła, gdyż w następnych latach kilkakrotnie jeszcze zmieniał miejsce zamieszkania, wynajmując kolejne lokale ${ }^{22}$.

Wspomniane wyżej noty słownikowe zawierają także informacje o dziełach Bröllmannów. Niestety, o ile odnotowują one nowe ustalenia biograficzne, to zarazem nie są wolne od pomyłek i błędów w zakresie danych o zabytkach. Dotyczy to zwłaszcza tekstów opracowanych przez Janusza Tandeckiego, w których autor powtórzył za starszą literaturą błędne, zweryfikowane już uprzednio informacje. Mylnie przyporządkował on niektóre zabytki poszczególnym warsztatom oraz podał nieprawdziwe atrybucje. Należy zatem skorygować, że sukienka na obraz Matki Bożej w Brdowie jest dziełem Niklausa, a nie Johanna ${ }^{23}$. Autor odnotowuje także parę ampułek mszalnych w kościele Najświętszej Marii Panny w Toruniu autorstwa starszego Bröllmanna - w rzeczywistości nieistniejących. Zapewne chodzi tu o pochodzące z Przeczna ampułki $\mathrm{z}$ tacą $\mathrm{w}$ zbiorach Muzeum Narodowego w Poznaniu (przypuszczalnie pomyłkowo odczytano i rozwiązano tu skrót MNP jako NMP) $)^{24}$. Podobnie

- po 7 września 1731 roku lub w początku 1732 roku, Dygdała przesuwa ją najdalej, na kwiecień 1732 roku, J. Dygdała, Urzędnicy miejscy Torunia, nr 808; dane przytoczone za: Księgi kiery (Kürbücher), APT, dz. I, t. 129. Ostateczną datę ustalił na podstawie akt kościelnych Krzysztof Mikulski (K. Mikulski, Pułapka niemożności, s. 136; za: APT, Gmina Ewangelicka Reformowana, 3, s. 315).

21 K. Mikulski, Pułapka niemożności, s. 137 (APT, Gmina Ewangelicka Reformowana, 3, s. 13, 316).

22 W 1726 roku wynajmował kamienicę przy ul. Szkolnej (nr domu 66), w latach 1728-1729 dom przy ul. Piekary (nr 212), w okresie 1733-1735 zajmował oficynę przy Szczytnej (nr 431), na koniec, w latach 1737-1738 miał mieszkanie przy Starotoruńskej (nr domu 233). K. Mikulski, Pułapka niemożności, s. 137.

23 J. Tylicki, Bröllmannowie, cz. II, kat. A1.

24 Ibidem, kat. 15. 
jeden z kielichów Niklausa znajduje się w Starogrodzie, a nie - jak u Tandeckiego - w Starogardzie ${ }^{25}$. Poważniejszym błędem jest informacja o używaniu przez tego rzemieślnika dwóch różnych znaków złotniczych, tzn. „NCB” lub „NB”. W rzeczywistości posługiwał się on jedynie pierwszą sygnaturą, trójliterową (w dwóch odmianach - wczesnej i późniejszej). Drugi znak jest powtórzeniem pomyłki wcześniejszych badaczy ${ }^{26}$. Ponownego sprostowania wymaga także informacja na temat warsztatu Samuela Bröllmanna, któremu autor, w oparciu o wcześniejszą literaturę, przypisuje autorstwo trzech kielichów (Obory, Toruń) oraz kubka z Muzeum Narodowego w Gdańsku. Jak wykazano uprzednio, są to $\mathrm{w}$ rzeczywistości prace innych toruńskich złotników ${ }^{27}$. Pewną zagadką pozostaje działalność tego mistrza, gdyż żadnych wykonanych przezeń wyrobów - ani drogą archiwalną, ani poprzez cechy złotnicze $-\mathrm{w}$ dalszym ciągu nie ujawniono ${ }^{28}$. Być może w trudnych ekonomiczne czasach wojny północnej zrezygnował on z założenia własnego warsztatu lub po krótkim czasie zaprzestał samodzielnej działalności? Mógł przez pewien czas pracować $\mathrm{w}$ warsztacie kierowanym przez matkę, a następnie w pracowni brata. We wszystkich trzech notach słownikowych wymieniany jest ponadto, jako pewne dzieło Johanna Christiana, pas srebrny z Muzeum Narodowego w Budapeszcie. Jak już wyjaśniono w katalogu dzieł Bröllmannów, schemat cechy mistrzowskiej widniejącej na tym przedmiocie odpowiada znakowi toruńskiego mistrza, jednak krój liter jest odmienny, brak także znaku miejskiego. Nie pozwala to na jednoznaczne określenie autorstwa zabytku ${ }^{29}$.

Szerzej należy odnieść się do nowej atrybucji, wskazanej przez Janusza Tandeckiego, a zamieszczonej w leksykonie Saura ${ }^{30}$. Wymienia

25 Ibidem, kat. 19.

26 Dwuliterową wersję cechy złotnika podaje mylnie Eugen von Czihak, por. J. Tylicki, Bröllmannowie, cz. I, s. 123. Informacje o znakach złotniczych wszystkich Bröllmannów porządkuje publikacja: M. Gradowski, A. Kasprzak-Miler, Złotnicy na ziemiach pótnocnej Polski, Część I: Województwo pomorskie, kujawsko-pomorskie i warmińsko-mazurskie, Warszawa 2002, nr T99, T115, T119.

27 J. Tylicki, Bröllmannowie, cz. II, s. 99-100.

28 Ibidem, cz. I, s. 99-100, cz. II, s. 99-100.

29 Ibidem, cz. II, s. 99.

30 Saur Algemeines Künstler-Lexikon, s. 330. 
on Johanna Christiana Bröllmanna jako współautora trumny sarkofagowej Księcia Janusza Radziwiłła w zborze ewangelickim w Kiejdanach na Litwie, powołując się przy tym na artykuł Birutè R. Vitkauskienė. Sarkofag, wykonany ze złoconej miedzi, powiązany został jednak przez wymienioną autorkę z toruńskim warsztatem złotnika Johanna Christiana Bierpfaffa ${ }^{31}$. Zabytek ten nie jest sygnowany, a badaczka dokonała atrybucji na podstawie podobieństw z sarkofagami królewskimi Władysława IV Wazy i Cecylii Renaty w kryptach królewskich katedry na Wawelu - potwierdzonymi dziełami Bierpfaffa. Zauważyła ona także, że w zabytku z Kiejdan widać różnice w sposobie opracowania różnych partii sarkofagu oraz jakości ich wykonania, co wskazuje, że powstawał on przy udziale kilku (co najmniej trzech) rzemieślników, zapewne czeladników Bierpfaffa. Badaczka nie wymienia jednak w tym kontekście nazwiska Bröllmannów, ani żadnych innych współpracowników. Obiekt powstał najprawdopodobniej pomiędzy 1669 a 1676 rokiem (dokładna data zlecenia i realizacji zamówienia nie jest znana). Wyklucza to w oczywisty sposób współautorstwo Johanna Christiana Bröllmanna, urodzonego w 1675 roku $^{32}$.

Z warsztatami Bröllmannów udało się w ostatnich latach powiązać osiemnaście kolejnych prac. Wiadomości o nowo odkrytych zabytkach są tym cenniejsze, że znalazły się w tej grupie w zdecydowanej większości przedmioty świeckie, jakich w dorobku obu toruńskich mistrzów było dotąd znanych wyjątkowo niewiele. Uzupełniają one naszą wiedzę na te-

31 B. R. Vitkauskienë, Sarkofag księcia Janusza Radziwiłła w Kiejdanach - dzieło toruńskiego złotnika Johanna Christiana Bierpfaffa, w: Niderlandyzm w sztuce polskiej. Materiały Sesji Stowarzyszenia Historyków Sztuki, Toruń, grudzień 1992, red. T. Hrankowska, Warszawa 1995, s. 215-224. Johann Christian Bierpfaff, złotnik, serwitor królewski, czynny w Krakowie i Warszawie, w Toruniu działał od ok. 1650 r., zmarł zaś w 1675 r. Bierpfaff, oprac. M. Woźniak, w: SBPN, t. I, s. 105-106; M. Gradowski, A. Kasprzak-Miler, Złotnicy na ziemiach północnej Polski, nr T69.

$32 \mathrm{~W}$ pracach nad sarkofagiem, o ile słuszne jest wiązanie go $\mathrm{z}$ warsztatem Bierpfaffa, mógłby teoretycznie uczestniczyć Niklaus Bröllmann, którego lata stażu czeladniczego w pracowni mistrza (1670-1672) pokrywają się częściowo z prawdopodobnym czasem powstania zabytku. Taka hipotetyczna możliwość nie jest jednak wystarczającą przesłanką do wskazania starszego Bröllmanna jako współautora tego dzieła. Za konsultacje i uwagi dotyczące sarkofagu kiejdańskiego dziękuję Marii Rdesińskiej, doktorantce w Instytucie Zabytkoznawstwa i Konserwatorstwa UMK w Toruniu. 
mat aktywności Bröllmannów w zakresie tej wytwórczości. Zważywszy na rzadkość sreber o świeckim przeznaczeniu w produkcji złotniczej Torunia w ogóle, są to przedmioty tym bardziej warte odnotowania.

Rozpoznane zostały również kolejne zabytki sakralne wykonane w warsztacie Niklausa Brolmana. Nieznanym wcześniej w dorobku mistrza przedmiotem jest niewielka lampa wieczna odnotowana na rynku antykwarycznym, o typowej dla tego rodzaju sprzętów formie (kat. 1). W dekoracji korpusu dominuje charakterystyczny dla złotnika motyw wici akantowej oraz dużych kwiatów, uchwyt łańcuchów natomiast zdobią uskrzydlone główki anielskie. Ciekawe są także dwa kolejne kielichy. Pierwszy, datowany około 1697 roku, obecnie w zbiorach katedry w Płocku (kat. 9), przypomina inne, znane uprzednio, dzieła tego mistrza, o typowej dla niego formie - $\mathrm{z}$ okrągłą, dość płaską stopą i gruszkowatym nodusem. Naczynie najbardziej zbliżone jest do kielicha z kościoła Wizytek w Krakowie ${ }^{33}$. W dekoracji dominuje wić akantowa, uzupełniona jedynie nielicznymi, drobnymi kwiatami. Brak jest, często spotykanych we wczesnych pracach mistrza, obfitych, dużych kwiatów czy pęków owoców. Pojawiają się natomiast, zarówno na stopie, jak i na koszyczku, ujęte w akantowe rezerwy, motywy Arma Chritst. Ten rodzaj dekoracji występuje również u działającego nieco wcześniej Stefana Petersena (choć jeszcze w otoczeniu dekoracji małżowinowej) ${ }^{34}$. Bardzo zbliżony typ prezentuje naczynie $\mathrm{z}$ warsztatu syna złotnika - kielich z $1709 \mathrm{roku}^{35}$. Powtarza się on także na wyrobach autorstwa ucznia Niklausa - Jacoba Weintrauba oraz na kielichu mistrza Johanna II von Hausena $^{36}$, związanego z pracownią młodszego Bröllmanna. Drugi wspomniany kielich, z kościoła parafialnego w Narzymie (kat. 8), powstały zapewne po 1690 roku, o analogicznym, klasycznym kształcie, jest - jako jedyny w dorobku Bröllmanna - całkowicie gładki, pozbawiony dekoracji. Ostatni rozpoznany zabytek sakralny to prosta, gładka patena znajdująca się w kościele parafialnym w Daniszewie (kat. 3).

33 J. Tylicki, Bröllmannowie, cz. II, kat. 4.

34 Np. kielichy w Małużynie (kościół par. pw. św. Wojciecha i Zwiastowania NMP) i Proboszczowicach (kościół par. pw. św. Floriana).

35 W zbiorach Muzeum Okręgowego w Toruniu, J. Tylicki, Bröllmannowie, cz. II, kat. 47.

36 Dzierzgoń, kościół par. pw. św. Trójcy. 
Wśród nowo zidentyfikowanych dzieł świeckich Niklausa znalazł się niewielki kubeczek z repusowaną dekoracją kwietno-akantową (kat. 6). Naczynie typowe, o prostej formie, wyróżnia się pozytywnie jakością zdobień - dobrze zakomponowanych i wykonanych z dużą precyzją i starannością. Wić akantowa wykazuje już lekko suchy charakter, co wskazuje, że mistrz śledził nowe tendencje w dekoracji i reagował na nie. Przedmiot jest także interesujący ze względu na znane osoby zleceniodawców - wykonany dla Salomona i Johanna Lüthken, członków Rady Miejskiej i kolejnych burmistrzów Torunia.

Wysoką klasę prezentuje niewielka, złocona patera ze zbiorów Ermitażu, również dekorowana motywami roślinnymi - symetrycznie skomponowaną wicią z dużych liści i kwiatów (kat. 7). Porównywalnym zabytkiem jest zbliżona wielkością, okrągła paterka gdańska Ernsta I Kadaua ${ }^{37}$. Wokół centralnego pola (tu jednak z przedstawieniem figuralnym) rozchodzą się podobnie symetryczne pary łodyg kwiatowych zakończone dużymi pąkami. Podobny układ ma także dekoracja roślinna na owalnej tacy innego złotnika gdańskiego, Hansa Polmanna ${ }^{38}$. O ile jednak dostrzec można podobieństwo motywów i ich kompozycji, to naczynie toruńskie cechuje znacznie obfitsza dekoracja. Kwiaty i listowie szczelniej wypełniają przestrzeń, są lepiej zakomponowane, prowadzone miękką, płynną linia, zróżnicowane, niezwykle plastyczne, starannie i precyzyjnie cyzelowane oraz fakturowane. Zabytek ten, nie odbiegając jakością od znanych już dzieł mistrza, po raz kolejny dowodzi jego nieprzeciętnych umiejętności w zakresie dekoracji repusowanej.

Równie wyjątkowa w złotnictwie toruńskim jest misa (patera) wysadzana numizmatami znana $z$ aukcji Sotheby's (kat. 4). Naczynie, niezwykle okazałe dzięki swoim rozmiarom i wadze (prawie trzykilogramowe), zdobi około 50 monet i medali. Na obszarze Prus numizmaty były dość powszechnie wykorzystywane do zdobienia wyrobów złotni-

37 Biblioteka Kórnicka PAN, nr inw. MK 3851; Aurea Porta Rzeczypospolitej. Sztuka Gdańska od połowy XV do końca XVIII w., red. T. Grzybkowska, Katalog wystawy Muzeum Narodowego w Gdańsku, Gdańsk 1997, s. 338-339, kat.VIII.82. (oprac. B. Dolczewska).

38 Petersburg-Ermitaż, nr inw. E10032; M. N. Łopato, Polskoje hudożestwiennoje sierebro XVII-pierwoj połowiny XIX wieka w Ermitaże, Petersburg 2004, s. 49, kat. gd 9. 
czych. Dla dzieła Bröllmanna wskazać można kilka analogii. Najbliższą wydaje się zaprezentowane na tej samej aukcji bardzo podobne naczynie o pruskiej proweniencji (nieznakowane), wysadzane monetami niemieckimi i szwedzkimi, datowane na początek XVIII wieku ${ }^{39}$. Pokrewne przykłady znane są także w złotnictwie gdańskim. Należy do nich misa monetowa z pokrywą autorstwa Johanna Jöde (około 1710-1720 roku ${ }^{40}$ czy waza Hieronima II Holla (przed 1730 rokiem) ${ }^{41}$.

Intrygującą, prawdopodobną pracą starszego Bröllmanna jest kufel monetowy z berlińskiego opałacu Charlottenburg (kat. 2), o którym jednak brak precyzyjnych informacji ${ }^{42}$. Warto go mimo wszystko odnotować jako jeden z nielicznych toruńskich kufli monetowych ${ }^{43}$. Zabytek ten, o prostej formie, graniastym uchwycie i oszczędnej dekoracji ma przede wszystkim liczne odpowiedniki w złotnictwie Królewca ${ }^{44}$.

Bardzo ciekawym i rzadko spotykanym przedmiotem jest teza doktorska, wykonana w 1702 r. dla Mateusza Rzepczyńskiego, obecnie w zbiorach Muzeum Narodowego w Krakowie (kat. 5). Potwierdza ona obronę rozprawy z zakresu filozofii w Academia Mariana w Toruniu. Nazwa uczelni pozostaje zagadkowa - najprawdopodobniej odnosi się ona do Kolegium Jezuickiego w Toruniu ${ }^{45}$. Nie udało się również, do tej

39 Sotheby's European Silver, Geneva, 15.11.1983, Lot 137.

40 Westpreußisches Landesmuseum Münster-Wolbeck, nr. inw. 92/323; Aurea Porta Rzeczypospolitej, s. 401, kat. IX.39, (oprac. J. Reisinger-Weber).

41 Kraków, Muzeum XX Czartoryskich, nr. inw. MNK-XIII-519.

42 Autorzy mieli okazję oglądać ten zabytek na ekspozycji muzeum (2002 r.), gdzie opisany on został jako dzieło Niklausa Bröllmanna, powstałe ok. 1690 r., nie było jednak wtedy możliwości zweryfikowania znaków złotniczych, umieszczonych najpewniej na dnie naczynia. Nie udało się także odnaleźć żadnej publikacji na jego temat, a dwie pisemne kwerendy (z 2003 i 2009 roku) pozostały bez odpowiedzi.

43 Znane są jeszcze dwa tego typu naczynia, znacznie różniące się od wzmiankowanego zabytku: kufel Johanna Viecka (T. Chrzanowski, M. Kornecki: Złotnictwo toruńskie. Studium o wyrobach cechu toruńskiego od wieku XIV do 1832 roku, Warszawa 1988, il. 238) oraz drugi, nieustalonego autorstwa (Gold-und Silberschmiedearbeiten vom 15.-19. Jahrhundert. Eine Wiesbadener Privatsammlung, Ausstellung im Städtischen Museum Wiesbaden, 8. Dezember 1968-28. Februar 1969, Wiesbaden 1968, kat. 115, il. 28).

44 Znanych jest blisko sto tego typu naczyń, kilkanaście prezentują m.in. A. Rohde, U. Stöver, Goldschmiedekunst in Königsberg, Stuttgart 1959, passim.

45 Niestety, nazwa taka nie pojawia się w żadnym opracowaniu dotyczącym szkoły toruńskiej lub innych szkół jezuickich. Nie udało się także odnieść jej do żad- 
pory, zidentyfikować licznych, wymienionych w treści inskrypcji osób. Można domyślać się wśród nich głównie przedstawicieli polskiej szlachty katolickiej z obszaru Prus, północnego Mazowsza i Wielkopolski - z niej to przede wszystkim rekrutowali się bowiem słuchacze szkoły toruńskiej ${ }^{46}$. Przedmiot ten stanowi interesujący dokument życia naukowego i literackiego w Toruniu, będąc punktem wyjścia do dalszych badań w tym kierunku. Pod względem formy i techniki zabytek cechuje dobrej jakości - jak zwykle u tego mistrza - repusowanie, słabiej prezentuje się natomiast grawerowana, figuralna scena Zwiastowania.

Do dorobku Johanna Christiana dodać można trzy kolejne sprzęty sakralne. Należy do nich kielich z kościoła parafialnego w Bądkowie Kościelnym (kat. 10), całkowicie gładki, bez dekoracji, analogiczny do kielicha z Muzeum w Toruniu ${ }^{47}$. Ze zbiorów prywatnych pochodzi para świeczników ołtarzowych (kat. 12), zbliżonych do kompletu z kościoła ss. Miłosierdzia w Chełmnie (niezwykle podobne, jedynie o niemal 1/4 niższe) oraz mających odpowiednik w dziełach współczesnego Bröllmannowi Jacoba Weintrauba. Złotnik posłużył się tu tymi samymi rozwiązaniami - zarówno w schemacie konstrukcyjnym, formie jak i motywach dekoracyjnych (równie sztywnych jak w uprzednio znanej parze lichtarzy jego autorstwa). Obecnie ujawnione świeczniki mają może tylko nieco lepsze, bardziej smukłe proporcje, uzyskane przez zwiększoną ilość pierścieni w trzonie. Potwierdza to naśladowczy często charakter prac młodszego Bröllmanna oraz jego zależność od zdolniej-

nej innej uczelni czy instytucji działającej w tym czasie. Jednakże w tekście wyraźnie mowa jest o szkole w Toruniu a treść inskrypcji wskazuje na jej katolicki charakter. Jedyną uczelnią katolicką prowadzącą katedrę filozofii w Toruniu było właśnie Kolegium Jezuickie.

46 S. Salmonowicz, Toruń w czasach baroku i oświecenia: szkice z dziejów kultury Torunia XVII-XVIII wieku, Warszawa 1982; K. Maliszewski, Zakony katolickie w Toruniu w XVII i XVIII w. okresie potrydenckim. „Studia Pelplińskie” 1987, t. XVIII, s. 33-57; L. Grzebień, Dzieje kulturalne jezuitów toruńskich (1596-1996), w: Jezuici $w$ Toruniu 1596-1996, red. K. Maliszewski, W. Rozynkowski, Toruń 1996, s. 55-83; L. Grzebień, Z dziejów kolegium jezuickiego w Toruniu w latach 1660-1772, w: Szlakami przeszłości i czasów współczesnych. Księga ofiarowana Profesorowi Lechowi Mokrzeckiemu zokazji Jego Jubileuszu, red. L. Mokrzecki, K. Puchowski, J. Żerko, Gdańsk 1996.

47 J. Tylicki, Bröllmannowie, cz. II, kat. 46. 
szego Jacoba Weintrauba. W Muzeum Okręgowym w Toruniu znajduje się korona - fragment aplikacji na obraz, pozyskana także ze zbiorów prywatnych (kat. 16). Zabytek ten wykazuje pokrewieństwa z podobną aplikacją z kościoła w Święcieńcu (por. Uzupełnienia kat. 44a, il. 10b). Choć obiekty te przedstawiają różne typy koron - otwartą (MOT) i zamkniętą (Święcieniec), to w obu powtarza się podobny schemat konstrukcji i dekoracji (szeroka obręcz ograniczona sznurami, trójkątne sterczyny otoczone bujnymi liśćmi akantu, repusowana imitacja kamieni w podobnym kształcie i układzie). W koronie ze Święcieńca sterczyny są jedynie zmniejszone, aby stworzyć miejsce dla szerokich kabłąków.

$\mathrm{Na}$ pierwszym miejscu wśród nowo ujawnionych przedmiotów świeckich autorstwa młodszego złotnika wymienić można trzy kubki znane z rynku antykwarycznego. Wszystkie one, o typowym kształcie i proporcjach, mają analogie $\mathrm{w}$ pracach innych złotników $\mathrm{z}$ Torunia i Prus. Pierwszy z nich, grawerowany kubek z herbami mieszczan toruńskich z 1707 roku (kat. 11), wyróżnia się wielkością i wagą jako naczynie reprezentacyjne, ale przede wszystkim - ze względu na okoliczności jego powstania i późniejsze losy - jest cennym dokumentem historycznym. Drugi zabytek, z około 1710 roku, z motywami kwiatowymi (kat. 17) zestawić można pod względem dekoracji z wcześniejszym kubeczkiem Stefana Petersena ${ }^{48}$ czy licznymi pracami złotników gdańskich ${ }^{49}$. Dzieło Bröllmanna jest od nich znacznie większe, przez co bardziej reprezentacyjne, jednak sama wić roślinna została tu skomponowana raczej nieudolnie (skupiona w środkowej partii korpusu, z dużymi fragmentami

48 Czynny w Toruniu 1660-po 1695 - Muzeum Narodowe w Gdańsku, nr inw. MNG/SD/154/MT; B. Tuchołka-Włodarska, Złotnictwo od XIV do XX wieku. Katalog Zbiorów Muzeum Narodowego w Gdańsku, Gdańsk 2005, s. 78, kat., il. III.17.

49 Np. kubek Petera II Rode (1654-1689/1707), D. Nowacki, Warsztat złotnika gdańskiego Petera II Rode, „Rocznik Historii Sztuki” 2002, t. XXVII, s. 121, kat. 30, il. 18; także kubek Johanna II Rode (1684-1720) z Muzeum Narodowego w Gdańsku, nr inw. MNG/SD/153/MT, B. Tuchołka-Włodarska 2005, Złotnictwo od XIV do XX wieku, s. 78, kat. il. III.16; ponadto wyrób Johanna Meinertsa (1680-1709), W blasku srebra. Srebra z XVI-XIX w. z ziem Rzeczpospolitej Obojga Narodów i współczesnej Polski ze zbiorów muzeów rosyjskich: Ermitażu w Sanki Petersburgu, Muzeów Moskiewskiego Kremla i Muzeum Historycznego w Moskwie [katalog wystawy Zamku Królewskiego w Warszawie, 11 września-19 listopada 2006 roku], red. A. Saratowicz-Dudyńska, Warszawa 2006, kat. 77. 
pustej przestrzeni, liście i łodygi oddane dość sztywno, brak płynności), a repusowany relief jest średniej klasy. Warto podkreślić występujące w obu kubkach, w Toruniu niezbyt często spotykane, a te powtarzające się w zabytkach Johanna Christiana, oparcie naczyń na kulach trzymanych w szponach (obok dwóch wymienionych, kubek z $1708 \mathrm{roku}^{50}$ ). Podobny zabieg zastosował także związany z warsztatem Bröllmanna Johann von Hausen $w$ pucharze cechu rzeźników toruńskich ${ }^{51}$.

Ciekawie prezentuje się naczynie z personifikacjami miesięcy wiosennych ujętych w kartusze, łączący technikę wysokiego reliefu i grawerunku (kat. 18). Kompozycje z repusowanych, plastycznych, ornamentalnych rezerw mieszczących grawerowane przedstawienia figuralne, rozpowszechnione były od połowy XVII wieku. W Toruniu wskazać można kubki Johanna Christiana Bierpfaffa $z$ lat 60. XVII wieku czy Jakoba Sachsa z następnej dekady, oba wysokiej klasy ${ }^{52}$. Dzieło Bröllmanna, o około czterdzieści lat późniejsze (data w inskrypcji: 1719), podobne jest zwłaszcza do naczynia Sachsa - poprzez analogiczne, wydłużone rezerwy, wydzielone wśród bujnej dekoracji roślinnej. Choć zabytek ma okazały wygląd, ustępuje on jednak jakością obu wymienionym, wcześniejszym naczyniom. Repusowanie jest tu wysokiej klasy, dość plastyczne, z miękko, płynnie rozłożonymi liśćmi i kwiatami wypełniającymi szczelnie całą przestrzeń. Zaskakuje natomiast rażąco niska jakość grawerowanych przedstawień figuralnych - sztywnych, określonych grubą, mało zróżnicowaną linią. Alegorie i personifikacje związane z porami roku należą do typowego repertuaru tematów na kuflach i kubkach $\mathrm{z}$ tego czasu, często wykonywanych w seriach kilku, a nawet kilkunastu naczyń, odpowiadających kolejnym miesiącom ${ }^{53}$. Ciekawą analo-

50 Por. J. Tylicki, Bröllmannowie, cz. II, s. 92-93, kat. 43.

51 Muzeum Okręgowe w Toruniu, nr inw. MT/S/1941; Klejnot w Koronie Rzeczypospolitej. Sztuka zdobnicza Prus Królewskich. Katalog wystawy Muzeum Narodowego w Gdańsku, red. Cz. Betlejewska, Gdańsk 2006, t. II, Katalog, s. 206, kat. III.44 (oprac. K. Kluczwajd).

52 T. Chrzanowski, M. Kornecki, Złotnictwo toruńskie. Studium o wyrobach cechu toruńskiego od wieku XIV do 1832 roku, Warszawa 1988, s. 56, 62, il. 103-104, $123-124$.

53 Dobry przykład stanowią liczne kufle z 3 ćwierci XVII wieku gdańskiego warsztatu mistrza P/HL (utożsamianego z Hansem Polmannem), jeden z nich (również z przedstawieniami wiosennymi) w zbiorach Muzeum Narodowego w Gdańsku, 
gią tematyczną pośród dzieł złotnictwa toruńskiego jest kufel z personifikacjami kwietnia, maja i czerwca autorstwa Stefana Petersena ${ }^{54}$.

Oryginalnym zabytkiem w dorobku Johanna Christiana i w skali całego dorobku złotniczego Torunia jest niewielka puszka na susz herbaciany (kat. 14), powstała zapewne około 1720 roku. Przedmiot wykonano zgodnie $\mathrm{z}$ ówczesną modą: profilowane ścianki dekorowane są ornamentem z motywów wstęgowo-cęgowych z kampanulami. Choć sam grawerunek jest raczej słabszej jakości, momentami nieprecyzyjny, to omawiana puszka dowodzi, że w warsztacie Bröllmanna juniora, jednak obok mocno tradycyjnych powstawały także przedmioty bardziej nowoczesne, odpowiadające modnym trendom.

Bez wątpienia najciekawszym wśród prezentowanych tu dzieł świeckich Johanna Christiana jest wszakże kufel z personifikacjami cnót teologicznych, oferowany na rynku antykwarycznym w okresie międzywojennym (kat. 13). Na uwagę zasługuje forma uchwytu, analogiczna jak w jednym z kufli Niklausa: syn korzystał zapewne $\mathrm{z}$ form odlewniczych pochodzących $z$ warsztatu ojca ${ }^{55}$. Przedmiot ten ma jednak także inną - jak się wydaje, bezpośrednią - analogię w złotnictwie toruńskim. Obiekt ten powstał w warsztacie Stefana Petersena (czynny 1660-po $\left.1695^{56}\right)$. Cechuje się on zarówno analogiczną kompozycją i motywami dekoracyjnymi (trzy kartusze otoczone liśćmi akantu, kobiece hermy), jak i podobnym tematem przedstawień (grawerowane personifikacje).

nr inw. MNG/SD/95/MT, B. Tuchołka-Włodarska 2005, Złotnictwo od XIV do XX wie$k u$, s. 66, 67, kat. il. III.2 (tam wskazówki bibliograficzne na temat pozostałych).

54 Zamek Królewski na Wawelu, Państwowe Zbiory Sztuki, nr inw. 1293; A. Fischinger, D. Nowacki, Złotnictwo dawnych Prus Królewskich i Ksiązęcych w zbiorach Zamku Królewskiego na Wawelu, Kraków 2000, kat. 15.

55 Odnotować jednak należy, że ten typ trójodcinkowego, wolutowego uchwytu powtarza się już co najmniej od lat 70. XVII wieku w wielu warsztatach Gdańska, a także Torunia i Elbląga - odlewy takie mogły być w powszechnym użyciu, wykonywane jako prefabrykaty dla wielu pracowni. Analogiczne ucha mają m.in. kufle gdańskie Hieronima I Holla (Zamek de Seneffe, Belgia, nr inw. 261) i Daniela Fridricha Myliusa (Gdańsk, Muzeum Narodowe, nr inw. MNG/SD/99/MT), czy kufel toruński Stefana Petersena (Państwowe Zbiory Sztuki, Zamek Królewski na Wawelu, nr inw. 1293).

56 Kufel notowany na rynku antykwarycznym: Bukowskis Internationella Auction Hösten 2004, Auktion No. 534, Stockholm, 30 XI-3 XII 2004, s. 253, nr 542; Grosse Kunstauktion nr 128, Kunstauktionshaus Schloss Ahlden, 29-30 IV 2005, nr 250. 
Różni się on natomiast dekoracją pokrywy i stopy oraz - nieznacznie - formą uchwytu i zdobieniem cokolika (il. 8a). Podobieństwo naczyń jest na tyle uderzające, że nie ulega wątpliwości, iż obaj złotnicy opierali się na tych samych wzorach (przynajmniej w zakresie partii repusowanych) lub też Bröllmann miał okazję znać $\mathrm{z}$ autopsji wcześniejsze dzieło Petersena. Z powodu braku szczegółowych zdjęć czy opisów trudno stwierdzić, na ile zbliżone są do siebie przedstawienia w kartuszach. Według informacji katalogowych są one różne (u Bröllmann - Wiara, Nadzieja, Miłość; u Petersena - Sprawiedliwość, Roztropność, Prawda), jednak sposób ujęcia - duże, pojedyncze postacie na tle prostego, architektonicznego sztafażu (o dość podobnym rozmieszczeniu i formach) - może wskazywać, że w zakresie dekoracji figuralnej obaj mistrzowie korzystali z identycznych lub pokrewnych wzorów graficznych.

Oba naczynia powstały zapewne w niewielkim odstępie czasowym - biorąc pod uwagę czas działalności obu pracowni, był to okres co najmniej pięciu lat, ale późniejszy z kufli wykonany został raczej w początkowym okresie aktywności młodszego Bröllmanna, u zarania XVIII wieku. Reprezentacyjne sprzęty tego rodzaju należą do typowych wyrobów w produkcji złotniczej wcześniejszego okresu - ostatniej ćwierci XVII wieku (przede wszystkim w Gdańsku, ale także w pozostałych miastach pruskich). W następnym stuleciu zauważyć można kryzys zarówno ilościowy, jak i jakościowy ich produkcji, aż do całkowitego zaniku tego typu przedmiotów ${ }^{57}$. Naczynie Bröllmanna należy jednak jeszcze do wyrobów bardzo okazałych. Wraz z analogicznym dziełem Petersena, wyróżnia się wśród świeckich zabytków toruńskich, zwłaszcza na tle pozostałych znanych kufli o znacznie skromniejszej dekoracji. Na podkreślenie zasługuje szczególnie zastosowanie wysokiego, niemal pełnoplastycznego repusu, dość rzadko spotykanego w tutejszej wytwórczości. Zdecydowanie niższej klasy wydają się natomiast motywy grawerowane (trudne jednak do wyczerpującej oceny z powodu słabej jakości zachowanych ilustracji). Zabytek wyróżnia się także pozytywnie na tle pozostałych prac młodszego Bröllmanna, nie ustępując jakościowo znakomitym dziełom ojca, co dowodzi wysokich umiejętności również tego złotnika.

57 A. Frąckowska, Gdańskie kufle srebrne XVIII w. - próba charakterystyki, w: Rzemiosło artystyczne w Prusach Królewskich, red. J. Kriegseisen, Gdańsk 2009. 
$\mathrm{Na}$ koniec należy wymienić kolejną łyżkę zidentyfikowaną w kolekcji w Stanach Zjednoczonych (kat. 15) - typową, analogiczną do dwóch innych takich prac omawianego mistrza, oraz mającą odpowiedniki w zabytkach z Gdańska i Torunia. Osobnej wzmianki wymaga ponadto odnotowany kilka lat temu na polskim rynku antykwarycznym falsyfikat pracy Johanna Christiana - owalna tacka z dekoracją regencyjną ${ }^{58}$. Na wyrobie tym widnieją bardzo czytelnie odbite znaki miejski i mistrzowski, o kroju liter i obrysie pola zdecydowanie odmiennym od historycznych sygnatur Bröllmanna.

Chociaż zestawione tu zabytki nie powodują zasadniczych zmian w ocenie twórczości obu mistrzów, to jednak znacząco uzupełniają ich dorobek. W przypadku Niklausa ważnym wzbogaceniem obrazu jego działalności jest pięć kolejnych przedmiotów o charakterze świeckim. Johann Christian natomiast - pomimo kryzysu politycznego i ekonomicznego, w czasie którego przyszło mu działać - wykonywał, co się obecnie potwierdza, dzieła bardzo różnorodne i często okazałe. Jego prace, choć niekiedy eklektyczne, czasem wręcz naśladowcze, odpowiadały jednak zmieniającej się modzie i nowym potrzebom odbiorców. Umiejętności techniczno-artystyczne tego toruńskiego mistrza prezentują, co wiadomo było już wcześniej, poziom nierówny. Dosyć dobrze, swobodnie posługiwał się on techniką repusowania, zdecydowanie gorzej - grawerunkiem. Obok sprzętów wyraźnie słabszych trafiają się w jego dorobku dzieła wysokiej jakości. Może wolno widzieć w tej dwoistości udział w produkcji pracowni młodszego brata Samuela, którego samodzielne wyroby nie zostały rozpoznane?

58 Przedmiot w latach 90. XX w. oferowany do zakupu m.in. Muzeum w Toruniu i Zamkowi Królewskiemu na Wawelu. 


\section{KATALOG DZIEŁ (w układzie alfabetycznym)*}

\section{PRACE NIKLAUSA BRÖLLMANNA}

\section{LAMPA WIECZNA, $1680 \mathrm{r}$.}

Srebro kute, repusowane, grawerowane, fakturowane

Wymiary:

wysokość: $17,5 \mathrm{~cm}$

ciężar: $802 \mathrm{~g}$

(dane według katalogu aukcyjnego)

Znaki złotnicze (na brzegu):

- miejski Torunia: T z dwiema kropkami u dołu, w kolistym obrysie

- imienny: monogram NCB w prostokącie

Własność: obecne miejsce przechowywania nieznane

Korpus o typowym kształcie, zbudowany $\mathrm{z}$ ażurowej wici akantowej i gałązek z kwiatami. Zwieńczenie w kształcie żołędzia. Podwieszony na zaczepie z trzema główkami anielskimi. Łańcuch metalowy, późniejszy.

Stan zachowania: dobry

Historia:

W 1998 r. oferowana na aukcji Christie's w Amsterdamie.

\section{Literatura:}

Christie's, Dutch And Foreign Silver, Judaica, Russian Works Of Art and Objects Of Vertu, sale 2375, Amsterdam, 26 May 1998, lot. 448.

* Brano pod uwagę nazwę miejscowości. W przypadku zabytków znanych z rynku antykwarycznego było to miejsce ostatniej aukcji. 


\section{KUFEL MONETOWY, ok. 1690 r.}

Srebro kute, odlewane, repusowane, monety srebrne

Wymiary:

wysokość: ok. $20 \mathrm{~cm}$

Znaki złotnicze (przypuszczalnie):

- miejski Torunia

- warsztatowy Niklausa Bröllmanna

Własność: Berlin - Charlottenburg, Schlossmuseum

Kufel cylindryczny z pokrywą i uchem. W korpus wmontowane monety polskie (m.in. trojaki Zygmunta III Wazy), ułożone w trzech rzędach.

Stan zachowania: bardzo dobry

Historia:

Brak danych. Na ekspozycji prezentowany wraz ze srebrami pochodzącymi z pałacu rodziny Dohnów w Słobitach (Prusy Wschodnie), być może wchodził w skład tamtejszych zbiorów lub pochodzi z innego majątku na terenie Prus (w opracowaniu dotyczącym pałacu nie jest wymieniony $\left.{ }^{59}\right)$.

Literatura: niepublikowany

59 C. Grommelt, Ch. von Mertens, Das Dohnasche schloss Schlobitten in Ostpreußen: unter Mitwirkung von Alexander Fürst zu Dohna, Lothar Graf zu Dohna und Christian Krollmann, Bau- und Kunstdenkmäller des Deutschen Osten. Reihe B, Band 5, red. G. Grundmann, Stuttgart 1962. 


\section{PATENA KIELICHOWA, 1690-1703 r.}

Srebro kute, grawerowane, złocone

Wymiary:

$\varnothing 14,6 \mathrm{~cm}$

(dane według karty IZK)

Znaki złotnicze (na brzegu kołnierza):

- miejski Torunia: T z dwiema kropkami u dołu, w kolistym obrysie (słabo czytelny)

- imienny: monogram NCB w prostokącie (G, K-M nr T99b) (odbity częściowo)

Własność: Daniszwo (powiat płocki), kościół parafialny pw. Przemienienia Pańskiego

Okrągła, z wydzieloną kryzą, gładka. Na kryzie grawerowany krzyż równoramienny w owalu.

Stan zachowania: dobry

Literatura:

Gradowski, Pielas 2006, s. 755, kat. 84/5. 


\section{MISA (PATERA) MONETOWA, po 1683-1703 r.}

Srebro kute, repusowane, fakturowane i cyzelowane, częściowo złocone, medale, monety srebrne

Wymiary:

szerokość: $31,8 \mathrm{~cm}$

ciężar: $2900 \mathrm{~g}$ (dane według katalogu aukcyjnego)

Znaki złotnicze (na brzegu czaszy):

- miejski Torunia: T z dwiema kropkami u dołu, w kolistym obrysie

- imienny: monogram NCB w prostokącie

Własność: obecne miejsce przechowywania nieznane

Czasza okrągła, z profilowanym brzegiem, oparta na kolistej, niskiej, gładkiej stopie o wklęsłym profilu. Na bokach dwa uchwyty w formie lwich głów trzymających obręcze. W korpus wmontowane medale z XVII w. oraz 44 monety niemieckie, polskie i austriackie (głownie saskie i brunszwickie). Stopa, uchwyty, numizmaty, brzeg i wnętrze czaszy złocone.

Na ściance można rozpoznać m.in. medal autorstwa Johanna Höhna mł. wybity w 1670 r. z okazji przymierza Polski i Austrii. Awers: Popiersie Michała Korybuta Wiśniowieckiego w peruce i wieńcu laurowym na głowie i napis w otoku: MICHAEL D.G. REX POL. M.D: LIT: PRUS: MAS: SAM:, sygn. u dołu I.H., Rewers: Orzeł Polski i Orzeł Habsburski na wstędze z napisem: CONCVORDES PERENNENT, Kula Ziemska pływająca po morzu, Oko Opatrzności i herb Wiśniowieckich, napis w otoku: SACRO AQUILAE NEXU COALESCUNT AUSPICE COELO. Po przeciwnej stronie medal $\mathrm{z}$ wizerunkiem Jana III, prawdopodobnie medal triumfalny z 1683 roku, autorstwa Joanna Höhna, awers. Popiersie Jana III i napis : IOAN:III D.G.REX. POLONIARUM; rewers. pod napisem NEC LUNA DUABUS dwa orły w chmurach nad panoramą Wiednia, niżej w owalu napis: VIENNA LIBERA/ TA AD MDCLXXXIII/ D XII SEPT. 
Stan zachowania: bardzo dobry

Historia:

W 1983 roku misa wystawiana na aukcji Sotheby's w Genewie jako pochodząca z kolekcji Bernoulli w Bazylei. Być może tożsama z naczyniem wzmiankowanym przez Czihaka w zbiorach Muzeum XX Czartoryskich w Krakowie, następnie prawdopodobnie zrabowanym w 1939 r. z Sieniawy przez żołnierzy niemieckich ${ }^{60}$ lub przedmiot analogiczny, stanowiący pierwotnie komplet $\mathrm{z}$ zaginionym.

Literatura:

Sotheby's European Silver, Geneva, 15.11.1983, Lot. 212.

60 J. Tylicki, Bröllmannowie, cz. II, „Acta Universitas Nicolai Copernici. Zabytkoznawstwo i Konserwatorstwo" 1994, z. XIX, kat. 25. 


\section{TABLICA - TEZA DOKTORSKA MATEUSZA RZEPCZYŃSKIEGO,} 1702 r.

Srebro kute, repusowane, grawerowane, cyzelowane

Wymiary: $28,5 \times 22 \mathrm{~cm}$

Znaki złotnicze (u dołu na obramieniu):

- miejski Torunia: T z dwiema kropkami u dołu, w kolistym obrysie

- imienny: monogram NCB w prostokącie (G, K-M nr T99b)

Własność: Kraków, Muzeum Narodowe nr inw. MNK-IV-Z-1080

Owalny, wypukły kartusz o obramieniu repusowanym, utworzonym z wici akantowej i rogów obfitości. W górnej części, na obramieniu para nagich, uskrzydlonych puttów, podtrzymujących wieniec laurowy oraz trzymających wstęgę z inskrypcją. W polu kartusza w górnej części grawerowane przedstawienie Zwiastowania z Marią siedzącą przy pulpicie pod namiotem (baldachimem) oraz Archaniołem Gabrielem ukazanym w obłoku, ponad nimi, centralnie gołębica Ducha Świętego. Poniżej przedstawienia grawerowany tekst.

Treść inskrypcji:

[w wieńcu laurowym górą] Tibi Corona

[na wstęgach puttów] Cursum Consumavim, [-] Certamen Certavimus [w polu kartusza]

Æternum VERBUM concipianti.

ADMIRABILI VIRGINI MATRI.

Conceptus dedicant Philosophicos

Devinctissimi Philosophi et Sodales.

Adam, . Grabiecki: Albert, . Stroniewski. Andreas Partkiewicz . Antoni, . Nieszczewsky Rojewsky

Blasi, Fordonski Francisco, .Browinski Łaszczynski. Pacoltowski. Smizynski. Georgi, Bastkowski. 
Jacob, . Brodzinski. Bystry. Piasecki. Ignati, . Heymowski. Joannes Szukajewski. Wachowski.

Matthæus Brzuszkiewicz. Laurentius Kolowski. Lesnicki. Matthias Olszynski. Rzep.

czynski. Michael Gulczewicz. Paul, Czarnowski Petr,. Piechowski. Michael.

Mazurowicz. Nowicki. Pomirski. Sebastian, . Ewertowski. Thomas Zagrzewski.

Valentin, . Sokołowski.

CONCLUSIONES EX UNIVERSA PHILOSOPHIA.

Logica est Scientia Speculativo-Practica directiva Operationum.

Intellectus \& vocum externarum. Admissa forma cadaverica. non. se.

quire. Beatissimam fore Matrem cadaveris. Impossibilitatâ muscâ

possibili impossibilitatur.

DEUS DATVR DEMONstRATIVE DEUS.

Defendentur publice â MATTHIa RZEPczynsKi Marianæ

Academia Assistente Torunii

Ao. 1702. Die 7ma. Julii.

Stan zachowania: bardzo dobry

Historia:

Zakupiona do Muzeum Narodowego w Krakowie w antykwariacie Adolfa Stieglitza w Krakowie przed 1939 r.

Literatura: niepublikowana 


\section{KUBEK, przed 1697 r.}

Srebro kute, repusowane, grawerowane, fakturowane i cyzelowane, częściowo złocone

Wymiary:

wysokość: $13,8 \mathrm{~cm}$

ciężar: $126 \mathrm{~g}$

(dane według katalogu aukcyjnego)

Znaki złotnicze (na dnie naczynia):

- miejski Torunia z ok. 1700 r.: T z dwiema kropkami u dołu, w kolistym obrysie

- imienny: monogram NCB w prostokącie (G, K-M nr T99b)

Własność: obecne miejsce przechowywania nieznane

Smukły, o konicznym kształcie, z nieznacznie wygiętą na zewnątrz wargą, stopa z szeroką, gładką kryzą, oddzielona od korpusu wąską, profilowaną obrączką. Korpus dekorowany repusowaną w niskim reliefie wicią akantową oraz dużymi, pojedynczymi pąkami kwiatowymi. Stopa, dolny i górny brzeg naczynia oraz wnętrze złocone. Przy górnym brzegu inskrypcja minuskułą kursywną: Salomon Ernestus Lütken/Johann Friederich Lütken i monogram majuskułą: KRK

Stan zachowania: bardzo dobry

Historia:

Fundowany przez Salomona i Johanna Friedericha Lütken (Lütke). (Salomon, sekretarz miast Torunia w latach 1671-1687, rajca 1687-1697, wicekamlarz 1689/1690, burmistrz miasta z roku 1697, zmarł rażony apopleksją, witając królową-wdowę Marię Kazimierę (29 IX 1697) ${ }^{61}$;

61 J. Dygdała, Urzędnicy miejscy Torunia: spisy. Cz. III: 1651-1793, Toruń 2002, nr 1152, 101, 19; J. E. Wernicke: Geschichte Thorns aus Urkunden, Dokumenten und Handschriften, 1842, s. 310 . 
Johann, sekretarz 1684-1694, ławnik 1694-1700, rajca 1700-1702, burmistrz 1702-170462). Data śmierci Salomona wyznacza datę ante quem wykonania naczynia. Kubek odnotowany w handlu antykwarycznym: dom aukcyjny HAMPEL w Monachium, aukcja 28 czerwca 2003 r. oraz powtórnie 20 września 2003 r. (cena uzyskana: 6.300 Euro).

\section{Literatura:}

Hampel Kunstauktionen München Grosse Juni-Auktion, Freitag 27. Juni / Samstag 28. Juni 2003 (Auktion Teil II, Samstag 28.6.2003), s. 384, Lot. 1726, il. s. 385.

Hampel Kunstauktionen München Grosse September-Auktion, Freitag 19. September / Samstag 20. September 2003 (September Auction Part II. Furniture, Sculpture, Old Master Paintings, Pharmacy, 20.9.2003), Lot. 1609.

http://www.hampel-auctions.com/en/51-111/archive/33025/ (14.02.2008)

62 J. Dygdała, Urzędnicy miejscy Torunia, cz. III, nr 1157, 249, 113, 22. 


\section{PATERA Z DEKORACJĄ ROŚLINNĄ, ok. 1690-1703 r.}

Srebro kute, repusowane, fakturowane i cyzelowane, złocone

Wymiary:

Ø: $27 \mathrm{~cm}$

Znaki złotnicze (na brzegu kołnierza):

- miejski Torunia: T z dwiema kropkami u dołu, w kolistym obrysie

- imienny: monogram NCB w prostokącie (G, K-M nr T99b)

Własność: Sankt Petersburg, Ermitaż - Państwowe Zbiory Sztuki, nr inw. E13507

Okrągła, z niewielkim, lekko zagłębionym lustrem i szerokim kołnierzem. Brzeg wygięty faliście. W centrum repusowana duża, symetryczna, liściasta rozeta, od której wychodzą w czterech kierunkach pędy, tworzące na kołnierzu bujną dekorację roślinną: długie, ozdobnie skręcone łodygi i liście akantu, zakończone dużymi, zróżnicowanymi pąkami kwiatowymi. W całości złocona.

Stan zachowania: bardzo dobry

Historia: Pozyskany do zbiorów muzeum w 1923 r. z kolekcji książąt Jusupowych.

Literatura:

M. N. Łopato: Polskoje hudożestwiennoje sierebro XVII-pierwoj połowiny XIX wieka w Ermitaże, Petersburg 2004, kat. To 1. 


\section{KIELICH MSZALNY 1690-1703 r.}

Srebro kute, grawerowane, złocone

Wymiary:

wysokość: $22,3 \mathrm{~cm}$

$\varnothing$ stopy: $13 \mathrm{~cm}$

(dane według karty IZK)

Znaki złotnicze (na kryzie stopy):

- miejski Torunia: T z dwiema kropkami u dołu, w kolistym obrysie

- imienny: monogram NCB w prostokącie (G, K-M nr T99b)

Własność: Narzym (powiat Działdowo), kościół parafialny pw. Jana Chrzciciela

Stopa okrągła, z szeroką kryzą. Nodus gruszkowaty, ujęty dwoma profilowanymi pierścieniami. Czasza bez koszyczka, z lekko wygiętą wargą. Kielich gładki, w całości złocony.

Stan zachowania: bardzo dobry

Literatura:

Gradowski, Pielas 2006, s. 755, kat. 348/1. 


\section{KIELICH MSZALNY, 1697 r.}

Srebro kute, repusowane, grawerowane, fakturowane, częściowo złocone

Wymiary:

wysokość: $29 \mathrm{~cm}$

$\varnothing$ stopy: $12,7 \mathrm{~cm}$

(dane według karty IZK)

Znaki złotnicze (na kryzie stopy):

- miejski Torunia: T z dwiema kropkami u dołu, w kolistym obrysie

- imienny: monogram NCB w prostokącie (G, K-M nr T99b)

Inskrypcje (na spodzie stopy):

Eccleae Woznicen 1697

Własność: Płock, kościół katedralny pw. Wniebowzięcia NMP (skarbiec)

Stopa okrągła, z szeroką kryzą, wysklepiona, repusowana, trzon stopy gładki. Nodus gruszkowaty, zdobiony repusowaniem, ujęty dwoma profilowanymi pierścieniami. Czasza szeroka, ujęta w ażurowy koszyczek. $\mathrm{Na}$ stopie w trzech owalnych rezerwach, utworzonych z liści akantu i pojedynczych kwiatów przedstawienia Arma Christi. Na smukłej szyjce stopy od góry stylizowane Liśce akantu. Nodus zdobiony od góry i dołu stylizowanymi liśćmi akantu. Koszyczek złożony z wici akantowej i pojedynczych pąków kwiatowych, wśród których umieszczono trzy plakiety z Arma Christi oraz uskrzydlone główki anielskie z podwieszonymi chustami.

Stan zachowania: płaszcz stopy przy trzonie lekko rozerwany

Historia:

Jak wskazuje treść inskrypcji, naczynie wykonane prawdopodobnie dla kościoła parafialnego pw. św. Michała Archanioła w Woźnikach (powiat płocki).

Literatura:

Gradowski, Pielas 2006, s. 755, kat. 433/19. 


\section{DZIEŁA JOHANNA CHRISTIANA BRÖLLMANNA}

\section{KIELICH MSZALNY, 1703-1727 r.}

Srebro kute, grawerowane, złocone

Wymiary:

wysokość: $24,8 \mathrm{~cm}$

$\varnothing$ stopy: $13,3 \mathrm{~cm}$

$\varnothing$ czaszy: $9,6 \mathrm{~cm}$

Znaki złotnicze (na kryzie stopy):

- miejski Torunia: T z dwiema kropkami u dołu, w kolistym obrysie z lat 1676-1728 (Gr. nr 6)

- imienny: monogram C/IB w trójliściu (Gr. K-M nr T115a)

Inskrypcje:

- na stopie wokół herbu inicjały: S-S / E-I / S-A / A-E / CA-P

- na spodzie stopy: Cong. Miss: Dom: Plo:

(dane według karty IZK)

Własność:

Bądkowo Kościelne (pow. płocki), kościół parafialny pw. św. Szczepana

Stopa okrągła, z szeroką kryzą. Nodus gruszkowaty, ujęty dwoma profilowanymi pierścieniami. Czasza bez koszyczka, z lekko wygiętą wargą. Kielich gładki, w całości złocony. Na stopie grawerowany herb Grabie $\mathrm{z}$ inicjałami.

Stan zachowania:

bardzo dobry 
Historia: Herb prawdopodobnie odnosi się do Seweryna Szczuki herbu Grabie: od 1703 r. biskup tytularny Joppe, generalny administrator i ekonom diecezji chełmińskiej, kanonik gnieźnieński, zmarły w 1727 roku $^{63}$. Później - według inskrypcji - przedmiot należał do płockiego konwentu zgromadzenia misjonarzy.

Literatura:

Gradowski, Pielas 2006, s. 755, kat. 7/3.

63 P. Nitecki, Biskupi kościoła w Polsce. Słownik biograficzny, Warszawa 1992, s. 199. 


\section{KUBEK Z HERBAMI MIESZCZAN TORUŃSKICH, 1707 r.}

Srebro kute, odlewane, grawerowane, częściowo złocone

Wymiary:

wysokość: $24,5 \mathrm{~cm}$

ciężar: $617 \mathrm{~g}$

Znaki złotnicze:

- miejski Torunia: T z dwiema kropkami u dołu, w kolistym obrysie

- imienny: monogram C/IB w trójliściu (G, K-M nr T115a)

Własność: Galeria Neuse - Kunsthandel Bremen

Wysoki, smukły, o konicznym kształcie, z nieznacznie wygiętą na zewnątrz wargą. Stopa z szeroką, gładką kryzą i niskim, profilowanym cokolikiem puncowanym w romby, wsparta na trzech podstawach (odlewanych) w formie kul trzymanych w ptasich szponach. Korpus dekorowany grawerowaniem. Na korpusie przedstawione trzy herby (tarcze herbowe z klejnotem i labrami) mieszczan toruńskich oraz towarzyszące im nazwiska fundatorów i inskrypcje.

Pod herbem Zernecke wtórna inskrypcja:

Dem Ur=Enkel Walter Ferdinand Zernecke, Stadtrath und Kämmerer, erster Vorsteher des Sicherheit=Vereins zum Andenken von mehreren Bürgen Danzigs, Dezember 1841

Stan zachowania: bardzo dobry

Herby odnoszą się do następujących osób:

Jacob Heinrich Zernecke, ur. 1672 r., uczeń Gimnazjów Akademickich w Toruniu i Gdańsku; w latach 1694-1699 studiował w Lipsku i Rostocku; sekretarz miejski w Toruniu 1699-1704, lawnik Starego Miasta 17061713, starszy ławy Starego Miasta 1712/13, rajca 1713-1723, starszy rajca $1720-1723$, burmistrz $1723-1731^{64}$. Po tumulcie przed kolegium 
jezuickim skazany na karę śmierci, jednak dzięki wielkiemu poważaniu i wpływom uniewinniony 12 grudnia $1724 \mathrm{r}$. Wyjechał następnie do Gdańska, pozostając jednak nadal czynnym burmistrzem Torunia. Dziejopisarz, autor Thornische Chronica 1231-1726 ${ }^{65}$.

Gottfried Giller, kupiec sukienny pochodzący z Wrocławia, członek III Ordynku 1723-1750, ławnik 1736-1750 $0^{66}$. Jego syn, także Gottfied, był później burmistrzem toruńskim ${ }^{67}$.

Christian Ruttig (Rutich), krawiec i kupiec sukienny, członek III Ordynku 1709-1716, ławnik przedmiejski 1713-1716, ławnik Starego Miasta $1716-1722^{68}$, przełożony gminy kościoła Mariackiego w Toruniu w 1722 roku $^{69}$.

Inskrypcja z 1841 r. dotyczy Waltera Friedricha Zernecke (Gdańsk 1790-1859), od 1823 r. skarbnika miejskiego, przewodniczącego wielu stowarzyszeń, przedstawiciela magistratu $\mathrm{w}$ towarzystwie strzeleckim (Friedrich-Wilhelm-Schützenbruderschaft), asesora wielu cechów gdańskich.

Historia:

Kubek ofiarowany w 1707 r. przez trzech wymienionych na naczyniu mieszczan, prawdopodobnie Radzie Miasta lub może jakiemuś bractwu w Toruniu. Przed 1841 r. zapewne zakupiony przez mieszczan gdańskich (nie jest jasne, w jakich okolicznościach), trafił jako podarunek do prawnuka jednego z fundatorów, który przekazał go potem córce Marii Zernecke. Następnie przeszedł na własność jej siostrzeńca Fritza Ilisch we Wrocławiu. Informacje na jego temat zamieszczone są w biografii rodziny.

65 W. F. H. Zernecke, Geschichte der Familie Zernecke, Bd 2, Jacob Heinrich Zernecke Bürgermeister und Chronist von Thorn (1672-1741). Riesenburg Westprreußen 1909.

66 J. Dygdała, Urzędnicy miejscy Torunia, cz. III, nr 601, 879.

67 Giller Gottfried (1709-1793), burmistrz toruński. Toruński Słownik Biograficzny, t. III, red. K. Mikulski, Toruń 2002, s. 71-72.

68 J. Dygdała, Urzędnicy miejscy Torunia, cz. III, nr 280, 571, 817.

69 Altpreussische Biographie, Bd. 4, 1989. 
Literatura:

W. F. H. Zernecke, Geschichte der Familie Zernecke, Bd 2, Jacob Heinrich Zernecke Bürgermeister und Chronist von Thorn (1672-1741), Riesenburg Westprreußen 1909, s. 105 (określony jako kufel „Humpen”, ale opis i wymiary odpowiadają omawianemu zabytkowi).

Richter 2001, s. 277-286.

Klejnot $w$ Koronie 2006, t. II, Katalog, s. 213-214, kat. III.55 (oprac. Ch. Bernheiden). 


\section{PARA ŚWIECZNIKÓW OLTARZOWYCH, 1700-1710 r.}

Srebro kute, odlewane, repusowane, cyzelowane, częściowo złocone

Wymiary:

\section{$\mathrm{ZK} / 601 / 1$}

wysokość: $64,3 \mathrm{~cm}$

podstawa: $20,8 \times 21 \times 21,1 \mathrm{~cm}$

$\varnothing$ talerzyka: $12,2 \mathrm{~cm}$

ciężar: $1492 \mathrm{~g}$

\section{$\mathrm{ZK} / 601 / 2$}

wysokość: $63,7 \mathrm{~cm}$

podstawa: $20,5 \times 19,5 \times 19,3 \mathrm{~cm}$

$\varnothing$ talerzyka: $12,2 \mathrm{~cm}$

ciężar: $1491 \mathrm{~g}$

Znaki złotnicze (na kryzie profitki i na stopie):

- miejski Torunia: T z dwiema kropkami u dołu, w kolistym obrysie (Gradowski 2001, nr 6)

- imienny: monogram C/IB w trójliściu (G.K-M nr T115a)

Własność: zbiory prywatne Ryszarda Janiaka, nr inw: ZK/601/1-2

ZK/601/1 - stopa w formie wysokiego, trapezoidalnego cokołu, o trzech wklęsłych płaszczyznach, o wolutowych narożach wsparta na trzech kulistych nóżkach. Na ściankach dekoracja komponowana symetrycznie wokół trzech gładkich, owalnych medalionów, złożona z wici gałązek suchego akantu i kwietnych taśm, wykonana w reliefie różnej wysokości. Trzon wysoki, złożony z nodusa ujętego parą spłaszczonych pierścieni (gałek) różnej wielkości, powyżej wydłużona tralka i kolejna spłaszczona gałka. Elenenty wypukłe ułożone naprzemiennie z gładkimi, wklęsłymi pierścieniami. Gałki puklowane, nodus u dołu puklowany u góry zdobiony fryzem $\mathrm{z}$ trzema główkami aniołków oddzielonymi kwiatami róży, tralka zdobiona w dolnej części liśćmi akantu. Profitka 
dwustopniowa, rozszerzona, w dolnej partii puklowana, na spodzie talerzyka fryz z owali ujętych w obwódki.

ZK/601/2 - kształt i dekoracja analogiczne, drobne różnice w wielkości i kształcie puklowanych gałek (bardziej spłaszczone).

Stan zachowania: bardzo dobry

Historia: brak danych

Świeczniki analogiczne w formie i dekoracji do pary lichtarzy (nieco wyższych) z kościoła ss. Miłosierdzia w Chełmnie (Tylicki 1994, s. 87, kat. 39).

Literatura:

Poradnik polskiego kolekcjonera, red. Ł. Gaweł, Kraków 2004, s. 201.

Pasja zbierania. Kolekcja Ryszarda Z. Janiaka. Katalog wystawy Muzeum Narodowe w Kielcach, Zamek Królewski w Warszawie. red. R. Z. Janiak, R. de Latour, A. Kwaśnik-Gliwińska, Kielce 2007, s. 410, kat. II/82 (oprac. A. Kwaśnik-Gawlińska). 


\section{KUFEL Z ALEGORIAMI WIARY NADZIEI I MIŁOŚCI, 1700- $-1719 \mathrm{r}$.}

Srebro kute, odlewane, repusowane, grawerowane, cyzelowane, częściowo złocone

Wymiary:

wysokość: $20,5 \mathrm{~cm}$

Znaki złotnicze:

- miejski Torunia: T (brak dokładnego opisu)

- imienny: monogram C/IB w trójliściu (R2 nr 3645)

Własność: obecne miejsce przechowywania nieustalone

Cylindryczny z pokrywą i uchem. Korpus dekorowany repusowaniem i grawerunkiem, ujęty u dołu niskim, profilowanym cokolikiem puncowanym w romby. Stopa i pokrywa analogicznego kształtu, z szerokimi, gładkimi kryzami, wysklepione w kształt ćwierćwałka, dekorowane repusowaniem. Wierzch pokrywy nieznacznie podwyższony, gładki, grawerowany. Ucho i uchwyt pokrywy odlewane. Uchwyt pokrywy w kształcie dwóch rozchylonych w kształt litery „V” wolutek. Ucho o kształcie trójodcinkowej, masywnej woluty zbudowanej $\mathrm{z}$ form ornamentu małżowinowego. Na korpusie wydzielone trzy owalne rezerwy (kartusze), których obramienie stanowią wolutowo zwinięte, duże, mięsiste liści akantu. Pomiędzy kartuszami repusowane duże kobiece hermy wplecione w liście akantu oraz pęki owoców. W kartuszach przedstawione grawerowane personifikacje cnót teologicznych: Wiary, Nadziei i Miłości (według opisu katalogowego). Na stopie i pokrywie dekoracja złożona z liści akantu, pojedynczych dużych pąków kwiatowych i owoców. W centrum pokrywy przedstawienie pelikana, prawdopodobnie grawerowane.

Historia:

W 1930 roku wystawiany w domu aukcyjnym Hugo Helbinga w Monachium. 
Literatura:

Altes Kunstgewerbe, Glas, Keramik, Metallarbeiten, alte Gemälde und Skulpturen, Ostasiatica, Teppiche aus Hochfürstlichem Besitz sowie aus Reinischem Privatbesitz und anderem Besitz. Versteigerung in der Galerie Hugo Helbing München, 4-5 April 1930, München 1930, s. 13, kat. 150, il. Tab. III. 


\section{PUSZKA NA SUSZ HERBACIANY (HERBATNICA), ok. 1720 r.}

Srebro kute, repusowane, grawerowane, fakturowane, puncowane i cyzelowane, częściowo złocone

Wymiary:

wysokość: $12,8 \mathrm{~cm}$

rozmiary dna: $8 \times 5,5 \mathrm{~cm}$

Znaki złotnicze (na dnie naczynia):

- miejski Torunia: T z dwiema kropkami u dołu, w kolistym obrysie

- imienny: monogram C/IB w trójliściu (G. K-M nr T115a)

Inskrypcje:

- na górnej ściance, po obu stronach korka, grawerowany monogram:F. L.

- na dnie wydrapane niedbale litery: MS/J (MS/T?)

Własność:

Westpreußisches Landesmuseum, Münster-Wolbeck, nr inw. 92/235

Naczynie o kształcie zbliżonym do prostopadłościanu. Dno płaskie na planie prostokąta o ściętych, lekko wklęsłych narożach i wypukłych bokach. Korpus o wklęsłych narożach i wypukłych ściankach. Górna ścianka na brzegach kopulasto wysklepiona i faliście profilowana, w centrum płaska $\mathrm{z}$ niskim, umieszczonym centralnie, cylindrycznym wylewem. Puszka zamknięta srebrnym korkiem - u dołu cylindryczny, powyżej wąskiej kryzy przechodzący w stożek, zwieńczony niewielką odlewaną gałką. Ścianki naczynia zdobione dekoracją ornamentalną rozmieszczoną strefowo - skupioną na brzegach pionowych ścianek naczynia, na górnej ściance oraz na korku powyżej kryzy. Dekoracje tworzy ornament wstęgowo-cęgowy, pojedyncze liście suchego akantu i drobne, schematycznie potraktowane pąki kwiatowe. Ornament wykonany w niskim reliefie, uzupełniony grawerowaniem i cyzelunkiem, uwypuklony przez zmatowienie drobnymi puncynami i pozłocenie tła. Tło w partiach ornamentalnych, wklęsłe narożniki ścianek, korek powyżej kryzy oraz jego dolny brzeg, wnętrze puszki i korka złocone. 
Stan zachowania: bardzo dobry

Historia:

Zakupiona do muzeum na rynku antykwarycznym w 1992 roku.

Literatura: niepublikowana 
15. ŁYŻKA, ok. 1705-1710 r. (?)

Srebro kute, odlewane, cyzelowane, grawerowane, złocone

Wymiary:

długość: $19,3 \mathrm{~cm}$

Znaki złotnicze (na odwrocie czerpaka, od strony trzonka):

- miejski Torunia: T z dwiema kropkami u dołu, w kolistym obrysie

- imienny: monogram C/IB w trójliściu (G. K-M nr T155a)

Własność: USA, zbiory prywatne

Czerpak zbliżony w kształcie do okręgu, dość płytki, połączony z nartem uskokowo, o prostym, rozszerzającym się ku końcowi, czworokątnym w przekroju trzonku. Trzonek zakończony pełnoplastyczną, kobiecą hermą (główka kobieca z fryzurą z epoki), osadzoną na wolucie, poniżej, schodzące w dół po trzonku piętnaście pełnoplastycznych perełek. W katalogu Hungarian Silver autor mylnie określony jako: Johannes Behunek, Trencsén, Węgry (obecnie Trenčín/Trenczyn, Słowacja).

Zabytek analogiczny $\mathrm{z}$ dwoma innymi egzemplarzami wykonanymi przez Bröllmanna, przechowywanymi w zbiorach Muzeum Uniwersytetu Jagiellońskiego ( $\mathrm{nr}$ inw. 9292, 9293). Podobne łyżki znane są także $\mathrm{z}$ warsztatów złotników gdańskich: m.in. komplet trzech łyżek $\mathrm{z}$ analogicznymi hermami autorstwa Henricka Probsta i Johanna Conrada Stentzela (Fundacja zbiorów im. Ciechanowieckich przy Zamku Królewskim w Warszawie, nr inw. FC-ZKW 1406/1, 1606/2, 1406/3) czy niemal identyczna łyżka z pracowni tego ostatniego złotnika (Muzeum UJ, nr inw. 9294) ${ }^{70}$.

70 Informacje o zabytkach gdańskich za: „...łyżek srebrnych dwa tuziny.” Srebra domowe w Gdańsku 1700-1816. Katalog wystawy w Domu Uphagena, Gdańsk, lipiec-listopad 2007, red. J. Kriegseisen, E. Barylewska-Szymańska, współpraca W. Szymański, Gdańsk 2007, kat. I.12.1, I.12.5. 
Stan zachowania: bardzo dobry

Historia: brak danych

Literatura:

J. H. Kolba, Hungarian Silver. The Nicolas M. Salgo collection, London 1996, s. 85, kat. 63. 
16. KORONA, FRAGMENT APLIKACJI, ok. 1720 r.

Srebro kute, repusowane, grawerowane, cyzelowane i fakturowane, częściowo złocone

Wymiary: 14,5 x 21,5 x $1,4 \mathrm{~cm}$

ciężar: $90 \mathrm{~g}$

Znaki złotnicze (po bokach środkowej sterczyny w formie trójkąta):

- miejski Torunia: T z kropkami, zbliżony do znaku z lat 1728-1745, ale górna belka litery T lekko skośna ku środkowi, kropki po bokach umieszczone niesymetrycznie

- imienny: C/IB w trójliściu, podwójnie bita, przez co mało czytelna (G, K-M, nr T115a)

Własność: Muzeum Okręgowe w Toruniu, nr inw. MT/S/10406

Fragment aplikacji na obraz. W części dolnej szeroka obręcz, organiczna na brzegach dwoma sznurami, zdobiona imitacją kameryzacji - na środku raut, na bokach dwa kaboszony, wokół nich osiem mniejszych kaboszonów. W części górnej pięć trójkątnych sterczyn (środkowa i skrajne większe) zdobionych liśćmi akantu, zwieńczonych kwiatonami. Tło sterczyn jednolite, fakturowane. W blasze pięć symetrycznych otworów do mocowania.

Stan zachowania: bardzo dobry

Historia:

Pochodzi z prywatnej kolekcji w Częstochowie. Poprzedni właściciel nabył koronę od osoby prowadzącej po II wojnie światowej skup antyków. Zakupiona do MOT w 1993 r.

Wystawy:

- 1994 Toruń, MOT, Sztuka sakralna nowożytnego Torunia (wystawa stała)

- 1996 Toruń, MOT, Nabytki MOT w latach 1993-1996

Literatura:

Gradowski, Pielas 2006, s. 755, kat. 606/29. 


\section{KUBEK, ok. 1710 r.}

Srebro kute, repusowane, grawerowane, fakturowane, puncowane i cyzelowane, częściowo złocone

Wymiary:

wysokość: $25,2 \mathrm{~cm}$

ciężar: $810 \mathrm{~g}$ (według informacji z Wawelu: $820 \mathrm{~g}$ )

$\varnothing$ wylewu: $14,3 \mathrm{~cm}$

(dane według katalogu aukcyjnego)

Znaki złotnicze (przy górnym brzegu naczynia):

- miejski Torunia: T z dwiema kropkami u dołu, w kolistym obrysie

- imienny: monogram C/IB w trójliściu (G. K-M nr T115a)

Własność: obecne miejsce przechowywania nieznane

Wysoki, smukły, o konicznym kształcie, z wygiętą na zewnątrz wargą. Stopa $z$ szeroką, gładką kryzą i niskim cokolikiem puncowanym $\mathrm{w}$ romby, wsparta na trzech podstawach $\mathrm{w}$ formie kul trzymanych w ptasich szponach. Korpus dekorowany repusowaną wicią akantową o mięsistych, szerokich liściach, tworzącą trzy rezerwy, w których ukazano duże pąki kwiatowe połączone łodygami z okalającym akantem. Górny brzeg, stopa wraz z cokolikiem i wnętrze naczynia złocone.

Stan zachowania: bardzo dobry

Historia:

Kilkakrotnie odnotowany w handlu antykwarycznym:

- w 1997 r. oferowany do zakupu Państwowym Zbiorom Sztuki na Wawelu;

- w 2005 r. na aukcji: Dom Aukcyjny AGRA ART, Warszawa, 22 maja 2005 r. (cena wywoławcza: $37.000 \mathrm{zl}$, uzyskana: $39.000 \mathrm{zł}$ )

http://www.agraart.pl/cgi-bin/obiekt.cgi?act=1\&qt=1221841766\&nr=68 $96(10.04 .2009)$

Literatura: niepublikowany 


\section{KUBEK Z PERSONIFIKACJAMI MIESIĘCY WIOSENNYCH, $1719 \mathrm{r}$.}

Srebro kute, repusowane, grawerowane, fakturowane, puncowane i cyzelowane, częściowo złocone

Wymiary:

wysokość: $21 \mathrm{~cm}$

ciężar: $560 \mathrm{~g}$

(dane według katalogu aukcyjnego)

Znaki złotnicze (przy górnym brzegu naczynia):

- miejski Torunia: T z dwiema kropkami u dołu, w kolistym obrysie $\mathrm{z}$ lat $1676-1728$ (Gr. nr 6)

- imienny: monogram C/IB w trójliściu (Gr. K-M nr T115a)

Inskrypcje:

- na dnie grawerowana data: ICB d 25 May Anno 1719 (prawdopodobnie rodzaj sygnatury $\mathrm{z}$ inicjałami złotnika)

Własność: w handlu antykwarycznym

Wysoki, smukły, o konicznym kształcie, z wygiętą na zewnątrz wargą, stopa z szeroką, gładką kryzą, oddzielona od korpusu cokolikiem pucowanym w rozetki. Na korpusie wydzielone trzy, symetrycznie rozmieszczone, wydłużone, owalne kartusze utworzone z bujnych z liści akantu, w których grawerowane postaci puttów: $\mathrm{z}$ siatką na motyle; obsiewające pole; głaszczące owce - personifikacje miesięcy wiosennych: kwietnia, maja, czerwca. Przestrzeń pomiędzy kartuszami wypełniona przez obfity, gęsty ornament złożony z wici akantowej i pojedynczych, dużych pąków kwiatowych (tulipanów). Grawerowane pola, obrzeże wylewu, stopa wraz z cokolikiem i wnętrze naczynia złocone.

Stan zachowania: bardzo dobry 
Historia:

Kilkakrotnie odnotowany w handlu antykwarycznym:

- Chriestie’s, Londyn, aukcja 11 czerwca 2002 r. (cena uzyskana $£ 7.285$ );

- dom aukcyjny Hampel w Monachium, aukcja 6 grudnia 2003 r. (wycena: 15.000 euro, niesprzedany);

- Galeria Neuse Bremen, 2006 r.

- F. Payer Kunsthandel, Zurich, wystawiany na targach TEFAF (The European Fine Art Foundation), Mastricht 2008.

\section{Literatura:}

Christie's, Silver And Plate, sale 9403, London, South Kensington, 11 June 2002, Lot. 34.

Hampel Kunstauktionen München Grosse Dezember-Auktion Freitag 5 Dezember / Samstag 6 Dezember 2003, (December Auction Part II. Furniture, Old Master Paintings, Sculpture, Silver, Samstag 6.12.2003) Lot. 552. (http://www.hampel-auctions.com/en/52-73/archive/34237/) (10.04.2009)

Klejnot $w$ Koronie 2006, t. II, Katalog, s. 211, kat. III.53 (oprac. Ch. Bernheiden) 


\section{UZUPEŁNIENIA i SPROSTOWANIA}

\section{Prace Niklausa Bröllmanna}

Kat. 1. Krzyż relikwiarzowy (1690-1693 r.), Chełmża, k. kolegiacki (d. katedra) pw. św. Trójcy

Lit.: Gradowski, Pielas 2006, s. 755, kat. 55/13.

Kat. 2. Kielich (ok. 1695 r.), Ciechocin, k. par. pw. św. Małgorzaty Lit.: Gradowski, Pielas 2006, s. 755, kat. 69/2.

Kat. 3. Tacka pod ampułki (ok. 1700 r.), Gniezno, k. katedralny pw. Wniebowzięcia NMP i św. Wojciecha

Lit.: Gradowski, Pielas 2006, s. 755, kat. 133/109.

Kat. 3a. Monstrancja (1680 r.), Górka Klasztorna, k. oo. Misjonarzy św. Rodziny pw. Niepokalanego Poczęcia NMP (pobernardyński) Lit.: Gradowski, Pielas 2006, s. 755, kat. 481/1.

Kat. 3b. Monstrancja (1685-1690 r.), Jabłkowo, k. fil. pw. św. Michała Archanioła

Lit.: Gradowski, Pielas 2006, s. 755, kat. 177/1.

Kat. 3c. Kufel, ok. 1695 r., w handlu antykwarycznym

Przed 1986 r. kufel oferowany na aukcji Herbert M. Ritter w Monachium.

Zabytek wyróżnia się ukazaniem ciągłej, rozbudowanej sceny rodzajowej, przy zastosowaniu wyłącznie techniki grawerunku. Podobną tematyką i techniką dekoracji posłużył się złotnik królewiecki, Matthäus I Bock na kuflu powstałym w podobnym czasie (datowany 1694 r.) przedstawiającym pejzaż wiejski z parą wędrowców (Schätze deutscher Goldschmiedekunst von 1500 bis 1920 aus dem germanischen Nationalmuseum, red. K. Pechstein, Berlin 1992, s. 194, kat. 73.) Lit.: Bachtler 1986, kat. 62, s. 142, il. s. 143; Frąckowska 2003, s. 60, kat. T5. 
Kat. 7a. Relikwiarz-ostensorium św. Apolonii (1690-1693 r.) Lubawa, k. par. pw. św. Anny

Lit.: Ars Sacra 1993, s. 88, kat. 137 (oprac. M. Woźniak); Klejnot w Koronie 2006, t. II, Katalog, s. 127, kat. II.59 (oprac. A. BaranowskaFietkiewicz); Gradowski, Pielas 2006, s. 755, kat. 290/11.

Kat. 8. Krzyż relikwiarzowy (1690-1695 r.), Lubraniec, k. par. pw. NMP Szkaplerznej

Lit.: Gradowski, Pielas 2006, s. 755, kat. 295/5.

Kat. 9. Łódka na kadzidło (1695 r.), Łopienno, k. par. pw. Wniebowzięcia NMP

Lit.: Gradowski, Pielas 2006, s. 755, kat. 310/8.

Kat. 10. Monstrancja (1695 r.), Łysakowo, k. par. pw. św. Antoniego Padewskiego

Lit.: Gradowski, Pielas 2006, s. 755, kat. 315/1.

Kat. 11. Monstrancja (1695 r.), Młyniec, k. fil. pw. św. Ignacego Loyoli

Lit: Gradowski, Pielas 2006, s. 755, kat. 339/1.

Kat. 11a. Kubek króla kurkowego (1694 r.), Norymberga, Germanisches Nationalmuseum

Lit.: Klejnot w koronie 2006, t. II, Katalog, s. 266, kat. III.136.

Kat. 12. Monstrancja (1694 r.), Okonin, k. par. pw. św. Kosmy i Damiana

Lit: Gradowski, Pielas 2006, s. 755, kat. 378/1.

Kat. 13. Monstrancja (1694 r.), Papowo Toruńskie, k. par. pw. św. Mikołaja bpa.

Lit: Gradowski, Pielas 2006, s. 755, kat. 409/1. 
Kat. 14. Podstawa relikwiarza na rękę św. Wawrzyńca (1690-1695 r.), Pelplin, pocysterski k. kat. pw. Wniebowzięcia NMP

Lit: Gradowski, Pielas 2006, s. 755, kat. 413/33.

Kat. 15. Ampułki z tacą (1695-1700 r.), Muzeum Narodowe w Poznaniu

Ampułki pochodzą z kościoła parafialnego pw. Podwyższenia Krzyża Świętego w Przecznie (powiat toruński), gdzie znajdowały się jeszcze w latach 80 . XX w. W dokumentacji KOBiDZ nadal figurują jako zachowane w kościele.

Lit: Gradowski, Pielas 2006, s. 755, kat. 463/4.

Kat. 16. Aplikacja (ok. 1695 r.), Przasnysz, k. klaszt. oo. Pasionistów pw. św. Jakuba Apostoł i św. Anny (pobernardyński)

Lit: Gradowski, Pielas 2006, s. 755, kat. 460/4.

Kat. 17. Aplikacja (ok. 1695 r.), Przasnysz, k. klaszt. pp. Kapucynek Klauzurowych pw. św. Klary i św. Józefa (dawniej pp. Bernardynek) Lit: Gradowski, Pielas 2006, s. 755, kat. 461/1.

Kat. 18. Kielich (ok. 1690 r.), Ryńsk, k. par. pw. św. Wawrzyńca Lit: Gradowski, Pielas 2006, s. 755, kat. 491/3.

Kat. 19. Kielich (ok. 1695 r.), Starogród, k. par. pw. św. Barbary Lit: Gradowski, Pielas 2006, s. 755, kat. 545/4.

Kat. 20. Kielich (1690-1695 r.), Toruń Muzeum Okręgowe - Ratusz Lit.: Ars Sacra 1993, s. 87-88, kat. 136 (opr. Michał Woźniak); Gradowski, Pielas 2006, s. 755, kat. 606/4.

Kat. 21. Monstrancja (1693-1694 r.) Wabcz, k. par. pw. św. Bartłomieja

Lit: Gradowski, Pielas 2006, s. 755, kat. 622/1. 
Kat. 24 (il. 13) Kubek, dawniej Gdańsk Provinzial-Muzeum

\section{KUBEK Z PERSONIFIKACJAMI CNÓT TEOLOGICZNYCH, 1675-1703 r.}

Srebro kute, repusowane, grawerowane, fakturowane, puncowane i cyzelowane

Wymiary:

wysokość: $18 \mathrm{~cm}$

$\varnothing$ wylewu: $11 \mathrm{~cm}$

(dane według katalogu)

Znaki złotnicze (przy górnym brzegu naczynia):

- miejski Torunia: T w kolistym obrysie

- imienny: monogram NCB w prostokącie

Inskrypcje:

- pod wylewem grawerowany napis: Oriana Christine von Keith [Kith?]

Własność: obecne miejsce przechowywania nieznane

Wysoki, konicznego kształtu, stopa z szeroką, gładką kryzą i niskim, profilowanym cokolikiem pucowanym w rozetki. Brzeg wylewu wzmocniony profilem. Na płaszczu korpusu repusowane trzy owalne kartusze złożone z ornamentu małżowinowego i liści akantu. Pomiędzy kartuszami repusowane pojedyncze kwiaty - tulipany, o dużych pąkach na długich, ulistnionych łodygach, rozmieszczone w parach po dwa, zwrócone pąkami ku brzegom naczynia. W kartuszach grawerowane przedstawienia, personifikacje: Wiary, Nadziei i Miłości (podpisane). Wśród zabytków bliższych czasowo wymienić można naczynia autorstwa złotników gdańskich, o podobnej kompozycji - z rezerwami umieszczonymi w górnej części korpusu i roślinną dekoracją poniżej, m. in. Christiana Bockhorna, Jacoba Meinertsa czy Jacoba Beckhausena ${ }^{71}$.

71 Berlin, Kunstgewerbemuseum, nr inw. 8867; Hamburg, Altonaer Museum, nr inw. 1984/210; Kraków, Muzeum Uniwersytetu Jagiellońskiego, nr inw. 9289. 
Historia:

W zbiorach Muzeum Rzemiosła Artystycznego Gdańsku od 1895 r. (nr inv. Kgm 2588), ewakuowany w 1943/1944.

Źródła:

Gdańsk, Archiwum Państwowe, sygn. APG 1384/11, odpis APG 1384/10, Westpr. Prov.-Konstgewerbemuseum, P.G.M. Verzeichnis der SchauSammlung 1881-1915, Bd. I, poz. I.45; Gdańsk, Archiwum Biblioteki Muzeum Narodowego w Gdańsku, sygn. MNG/A/VII/2, Verzeichnis der nach Herrengrebin versandten Kunstgegenstände, s. 7-18, poz. I.45; Gdańsk, Archiwum Biblioteki Muzeum Narodowego w Gdańsku, sygn. MNG/A/VII/2, Verzeichnis der fehlenden Silberkunstgegenstände, s. 360, 361, poz. 16; Gdańsk, Archiwum Biblioteki Muzeum Narodowego w Gdańsku, sygn. MNG/A/VII/12, Wykaz eksponatów zaginionych w okresie działań wojennych. Bursztyn; Złotnictwo; Cyna; Mosiądz, miedź, brąz, żelazo, poz. 15 .

Literatura:

Chrzanowski, Kornecki 1988, s. 177 [autorzy jednocześnie przedstawili analogiczny kubek jako dzieło J.C. Bierpfaffa, s. 115, il. 123-124, według Weltkunst, 1973, R. 43, il. s. 2118].

Woźniak SBPN, t. I, s. 165-167.

Tuchołka-Włodarska 2005, s. 124-125, poz. X.20.

Tuchołka-Włodarska 2005a, s. 75-170, poz. 74, s. 99.

Kat. 30. Podstawa krzyża relikwiarzowego (po 1690 r.), dawnie Poniatowo, k. par. pw. św. Wawrzyńca

Na stopie widnieje późniejsza z dwóch wersji znaku Niklausa, tym samym zabytek można datować ok./po $1690 \mathrm{r}$.

Krzyż znajduje się obecnie w zbiorach Westpreußisches Landesmuseum Münster-Wolbeck, nr inw. 92/322, wys. całości 49,8 cm, średnica stopy $17,7-18 \mathrm{~cm}$ 


\section{Prace Johanna Christiana Bröllmanna}

Kat. 38. Plakieta wotywna, (ok. 1720 r.) Chełmno, k. archiprezb. (farny) pw. Wniebowzięcia NMP

W katalogu KOBiDZu na podstawie znaku miejskiego datowana 1728-1732 .

Lit.: Więckowiak 2002, s. 220, 229 (błędnie podano lata działalności złotnika, 1790-1828); Gradowski, Pielas 2006, s. 755, kat. 51/101.

Kat. 39. Lichtarze - para (1715-1720 r.), Chełmno k. klasztorny ss. Miłosierdzia (dawniej pp. Benedyktynek) pw. św. Jana Chrzciciela i św. Jana Nepomucena

W katalogu KOBiDZu na podstawie znaku miejskiego datowane 1728-1732. Lit.: Gradowski, Pielas 2006, s. 755, kat. 52/4.

Kat. 42. Puszka na komunikanty (1702-1715 r.), Strzelno, k. par. pw. św. Trójcy (dawniej pp. Norbertanek)

Lit.: Gradowski, Pielas 2006, s. 755, kat. 557/3.

Kat. 43. Kubek (1708 r.), Stuttgart, kolekcja prywatna Lit.: Richter 2001, s. 277-286.

Kat. 44a (il. 10b) Korona wotywna, Święcieniec, k. par. pw. św. Anastazego i Wincentego

Srebro kute, repusowane, fakturowane, cyzelowane

Wymiary: $11,4 \times 15,5 \mathrm{~cm}$

Znaki złotnicze (centralnie, na obręczy korony):

- imienny: C/IB w trójliściu

- brak znaku miejskiego

(dane według karty IZK) 
Fragment aplikacji z nieokreślonego obrazu. W części dolnej szeroka obręcz, organiczna na brzegach dwoma sznurami, zdobiona imitacją kameryzacji - na środku raut, na bokach dwa duże i cztery mniejsze kaboszony. W części górnej pięć trójkątnych sterczyn (środkowa większe) zdobionych liśćmi akantu. Na przedłużeniu sterczyn pięć pałąków zdobionych repusowanymi guzami (imitacja kameryzacji), zwieńczonych kulą z krzyżem. W blasze trzy otwory do mocowania.

Korona w części dolnej (obręcz, sterczyny) podobna do zabytku w zbiorach Muzeum w Toruniu.

Stan zachowania: bardzo dobry

Lit.: KZSwP 10, 15, s. 98; Gradowski, Pielas 2006, s. 755, kat. 593/5.

Kat. 45. Kielich (1715 r.), Toruń, k. par. pw. św. Jana (farny) Napis od spodu stopy: Eccle Paro Toronen Anna Se(...)lska 1715.

W katalogu publikowanym w 1994 r. zamieniono informacje o dwóch kielichach z kościoła św. Jana - istniejącym (z inskrypcją fundacyjną z 1715 r., nr kat. 45) i zaginionym (dat. ok. 1725 r., nr kat. 51)

Lit.: Ornamenta ecclesiae 1999, s. 157, kat. LXXIX (oprac. M. Woźniak); Kluczwajd 2002, s. 46, 113, kat. 68; Domasłowski 2003, s. 217; Klejnot w koronie 2006, t. II, Katalog, s. 97, kat. II.21 (opr. Katarzyna Kluczwajd); Gradowski, Pielas 2006, s. 755, kat. 601/4.

Kat. 46. Kielich (1708 r.), Toruń, Muzeum Okręgowe - Ratusz Lit.: Woźniak 1998, s. 211-254, zw. s. 222; Gradowski, Pielas 2006, s. 755, kat. 606/6.

Kat. 47. Kielich (1709 r.), Toruń, Muzeum Okręgowe - Ratusz Lit.: Woźniak 1998, s. 211-254, zw. s. 222; Gradowski, Pielas 2006, s. 755, kat. 606/1. 
Kat. 51. Kielich (ok. 1725 r.), dawniej Toruń, k. par. pw. św. Jana (farny) W katalogu publikowanym w 1994 r. zamieniono informacje nt. pozycji katalogowych 45 i 51.

Kielich nr 51 nie posiadał inskrypcji. W literaturze datowany ok. 1725 r.

Kat. 53. Kielich (1705 r.), dawniej Toruń - Mokre, k. ew. pw. św. Jerzego

Lit.: Woźniak 1998, s. 211-254, zw. s. 222.

Kat. 54. Kielich (1709 r.), dawniej Toruń - Mokre, k. ew. pw. św. Jerzego

Lit.: Woźniak 1998, s. 211-254, zw. s. 222. 


\section{Skróty użyte w tekście}

Ars Sacra 1993 - Ars Sacra. Dawna sztuka diecezji toruńskiej. Katalog Wystawy Muzeum Okręgowego w Toruniu 5 XI-31 XII 1993, red. M. Woźniak, Toruń 1993.

Bachtler 1986 - Monika Bachtler: Goldschmiedekunst. Westfälische Privatsammlung. Bielefeld 1986.

Chrzanowski, Kornecki 1988 - T. Chrzanowski, M. Kornecki, Złotnictwo toruńskie. Studium o wyrobach cechu toruńskiego od wieku XIV do 1832 roku, Warszawa 1988.

Domasłowski 2003 - J. Domasłowski, Wyposażenie wnętrza, w: Bazylika katedralna św. Janów w Toruniu, red. M. Biskup, Toruń 2003.

Frąckowska 2003 - A. Frąckowska, „Srebrne kufle barokowe w Prusach Królewskich i Książęcych. Typologia naczyń wykonanych przez złotników pruskich w XVII i XVIII wieku" (maszynopis pracy magisterskiej, Uniwersytet Mikołaja Kopernika w Toruniu, 2003).

Gradowski, Pielas 2006 - M. Gradowski, M. Pielas, Katalog złotnictwa w zbiorze dokumentacji specjalistycznej Krajowego Ośrodka Badań i Dokumentacji Zabytków w Warszawie, część I. Warszawa 2006.

IZK - Instytut Zabytkoznawstwa i Konserwatorstwa Uniwersytetu Mikołaja Kopernika

Klejnot w koronie 2006 - Klejnot w Koronie Rzeczypospolitej. Sztuka zdobnicza Prus Królewskich. Katalog wystawy Muzeum Narodowego w Gdańsku, red. Cz. Betlejewska, t. I-II, Gdańsk 2006.

Kluczwajd 2002 - K. Kluczwajd, Skarby toruńskiej katedry. Katalog wystawy, Muzeum Okręgowe w Toruniu, marzec-maj 2002, Toruń 2002.

KZSwP - Katalog Zabytków Sztuki w Polsce.

Ornamenta ecclesiae 1999 - Ornamenta ecclesiae Poloniae. Skarby sztuki sakralnej X-XVIII w. Katalog wystawy, Zamek Królewski w Warszawie, 15 V-8 VIII 1999, red. A. Badach, P. Mrozowski, Warszawa 1999.

Richter 2001 - Ernst-Ludwig Richter, „Nach der ergrimten Pest, nach Bomben und Carcassen" Zwei Thorner Silberbecher aus der Zeit des Nordischen Kriegs, w: Studien zur europäischen Goldschmiedekunst des 14. bis 20. Jahrhunderts. Festschrift für Helmut Seling zum 80. Geburtstag am 12. Februar 2001, red. R. Eikelmann, A. Schommers, München 2001, s. 277-286. 
Tuchołka-Włodarska 2005 - B. Tuchołka-Włodarska, Złotnictwo od XIV do XX w. Katalog zbiorów Muzeum Narodowego w Gdańsku, Gdańsk 2005.

Tuchołka-Włodarska 2005a - B. Tuchołka-Włodarska, Straty wojenne w zbiorach bursztynu i metali Muzeum Miejskiego i Muzeum Zbiorów Artystycznych [Stadt- und Kunstgewerbemuseum] w Gdańsku, w: Straty wojenne Muzeum Miejskiego i Muzeum Rzemiosła Artystycznego $w$ Gdańsku, t. II: Straty $w$ dziedzinie rzemiosła artystycznego: meble, bursztyn, metale, red. I. Ziętkiewicz, Gdańsk 2005.

Więckowiak 2002 - J. Więckowiak, Piety pomorskie w rzeźbie, malarstwie i złotnictwie, Pelplin 2002.

Woźniak 1998 - M. Woźniak, Liturgische Gefäße der protestantischen Kirchen in Königlich Preußen, w: Kościół i sztuka pobrzeża Bałtyku/ Kirche und Kunst im Ostseeraum, „Studia Borussico-Baltica Toruniensia Historiae Artium”, t. III, red. M. Woźniak, Toruń 1998.

Woźniak SBPN - M. Woźniak, Bröllmanowie. w: Słownik Biograficzny Pomorza Nadwiślańskiego, t. I, s. 165-167. 



Il. 1. Autograf Johanna Christiana Bröllmanna z listu Gminy Kościoła reformowanego w Toruniu do Dawida Cassiusa, 1718 r. Archiwum Państwowe w Poznaniu, Akta Braci Czeskich 1557-1817 (Wielkopolska Biblioteka Cyfrowa: $w w w . w b c . p o z n a n . p l / d l i b r a / d o c c o n n e c t ? i d=54572$; 23.04.2009)

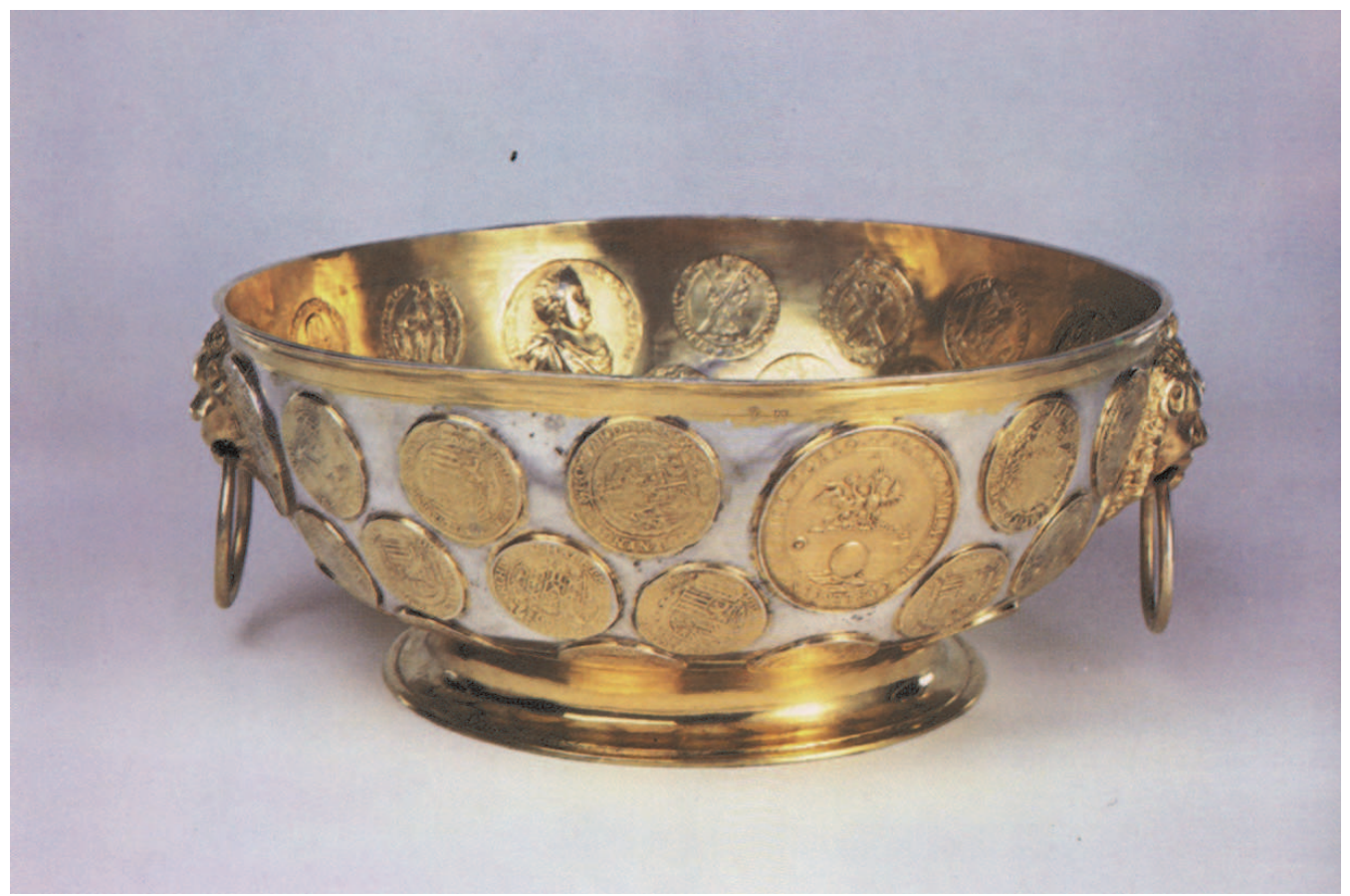

Il. 2. Niklaus Bröllmann, patera monetowa, po 1683-1703 r. (Sotheby's European Silver, Geneva, 15.11.1983, Lot. 212) 


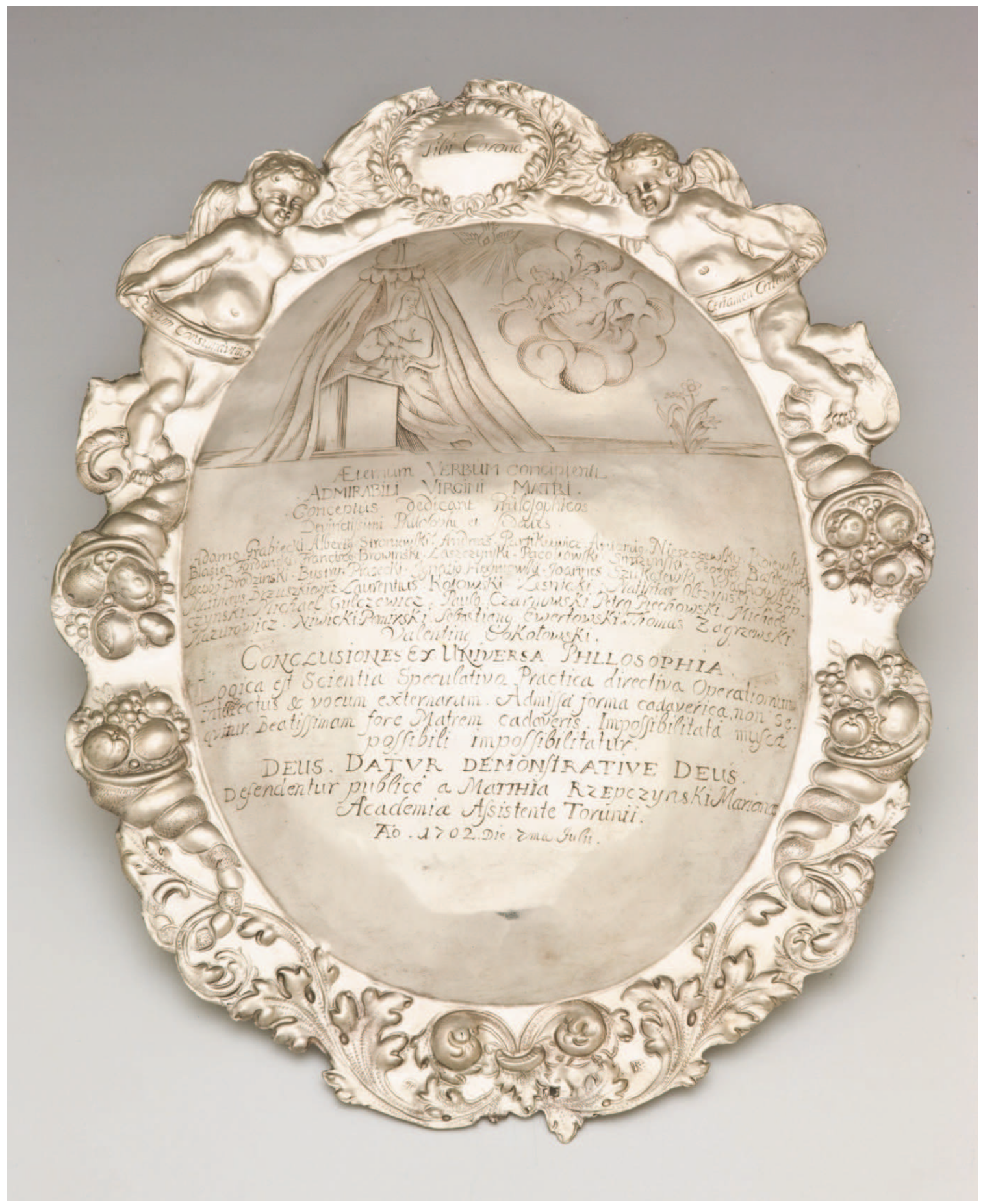

Il. 3. Niklaus Bröllmann, teza doktorska Mateusza Rzeprzyńskiego, 1702 r., Muzeum Narodowe w Krakowie (fot. Muzeum Narodowe w Krakowie) 


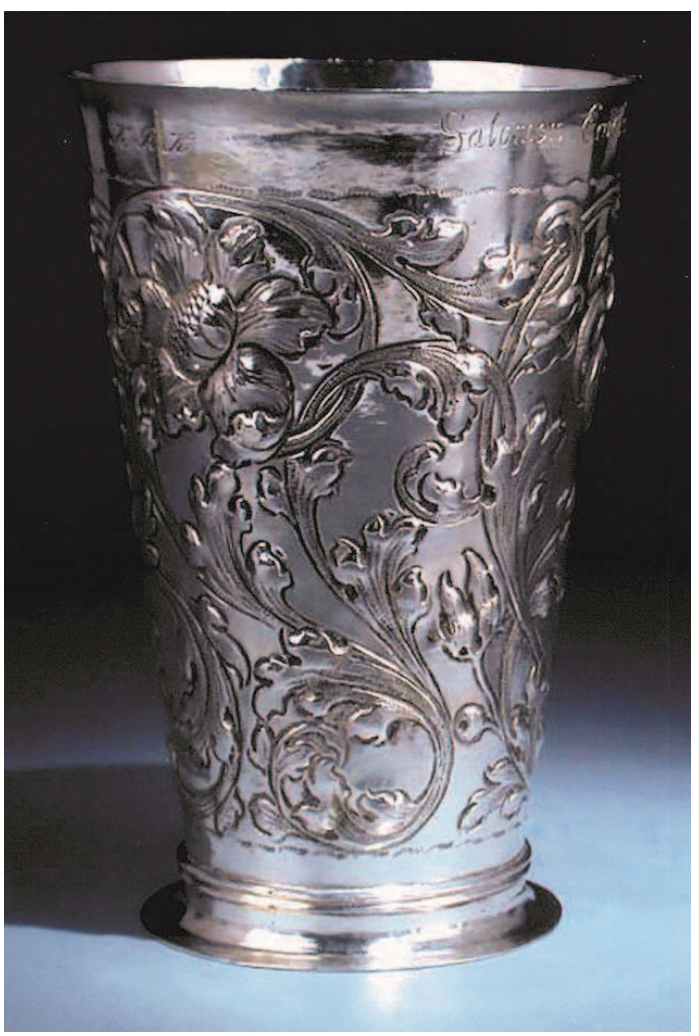

Il. 4. Niklaus Bröllmann, kubek, przed $1697 \mathrm{r}$.

(http://www.hampel-auctions.com/ en/51-111/archive/33025/; 14.02.2008)

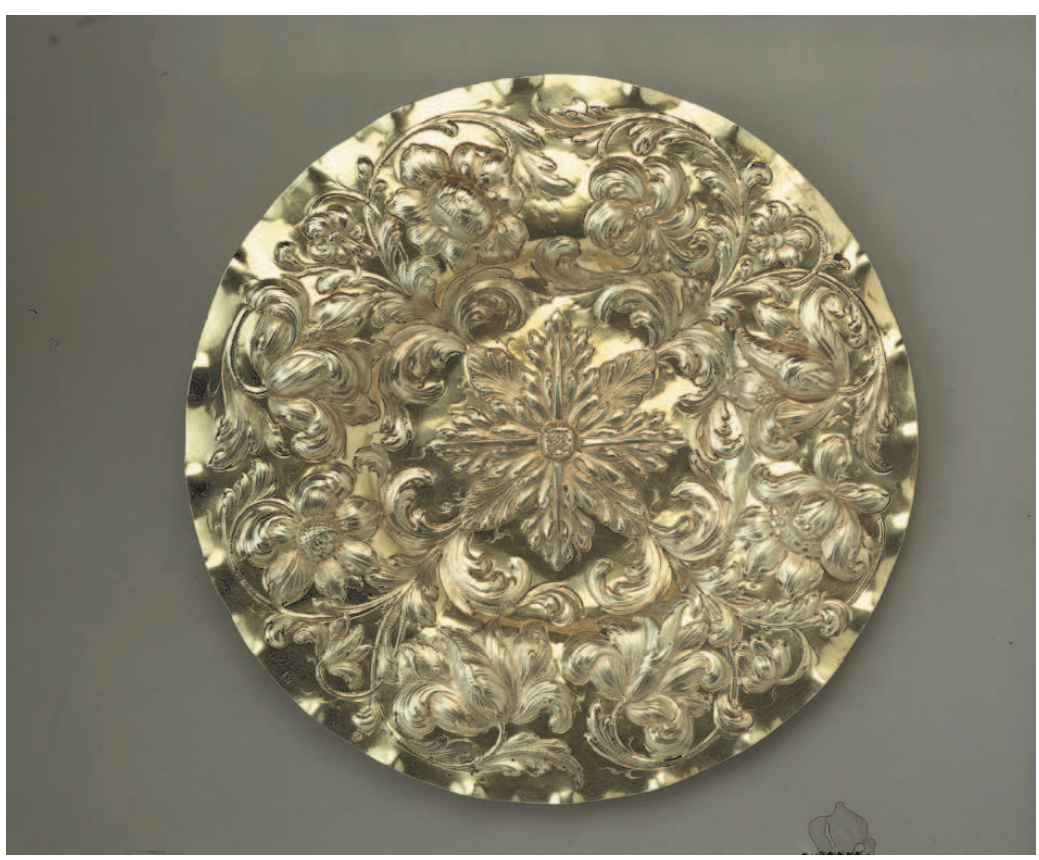

Il. 5. Niklaus Bröllmann, patera z dekoracją roślinną, ok. 1690-1703 r. (fot. za: M. N. Łopato, Polskoje hudożestwiennoje sierebro XVII-pierwoj połowiny XIX wieka w Ermitaże, Petersburg 2004, kat. To 1) 

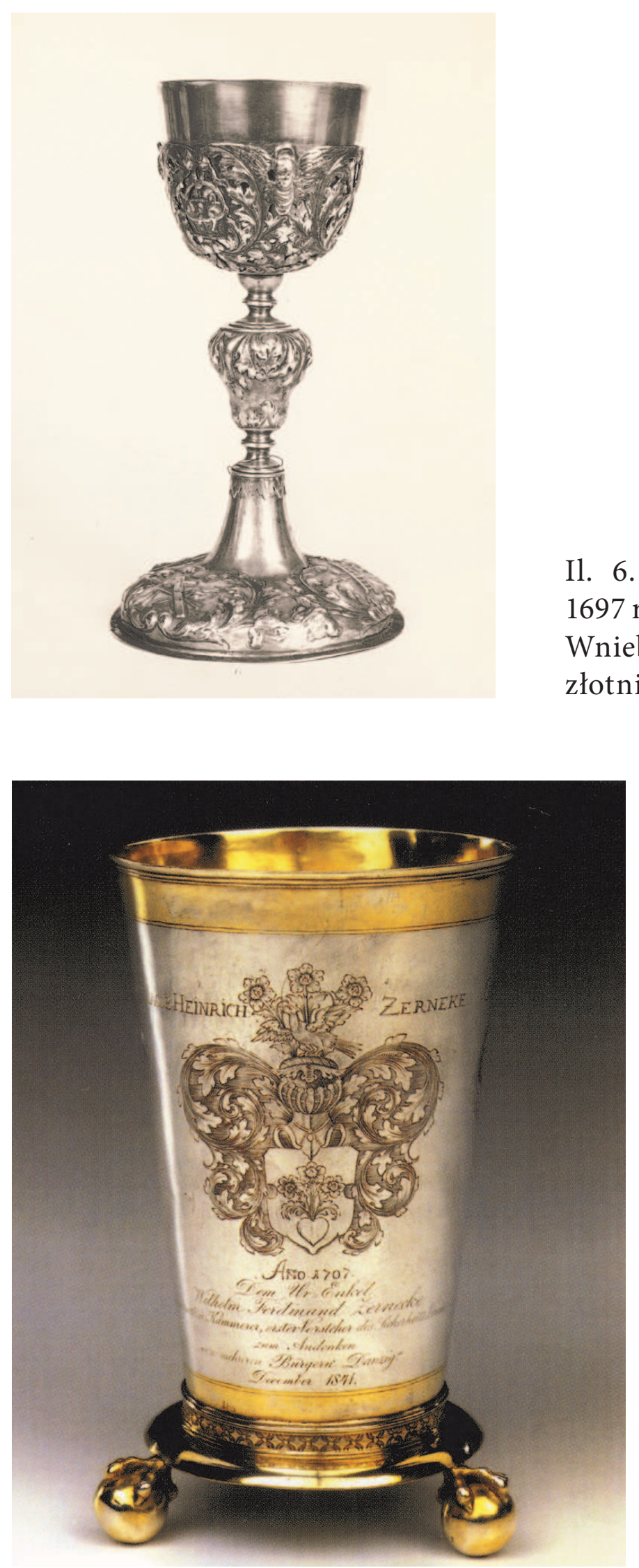

Il. 6. Niklaus Bröllmann, kielich, 1697 r., Płock, kościół katedralny pw. Wniebowzięcia NMP (dokumentacja złotnictwa IZK, fot. W. Górski)
Il. 7. Johann Christian Bröllmann, kubek $\mathrm{z}$ herbami mieszczan toruńskich, 1707 r. (fot. za: Klejnot w Koronie Rzeczypospolitej. Sztuka zdobnicza Prus Królewskich. Katalog wystawy Muzeum Narodowego w Gdańsku, red. Cz. Betlejewska, Gdańsk 2006, t. II, Katalog, s. 213-214, kat. III.55) 


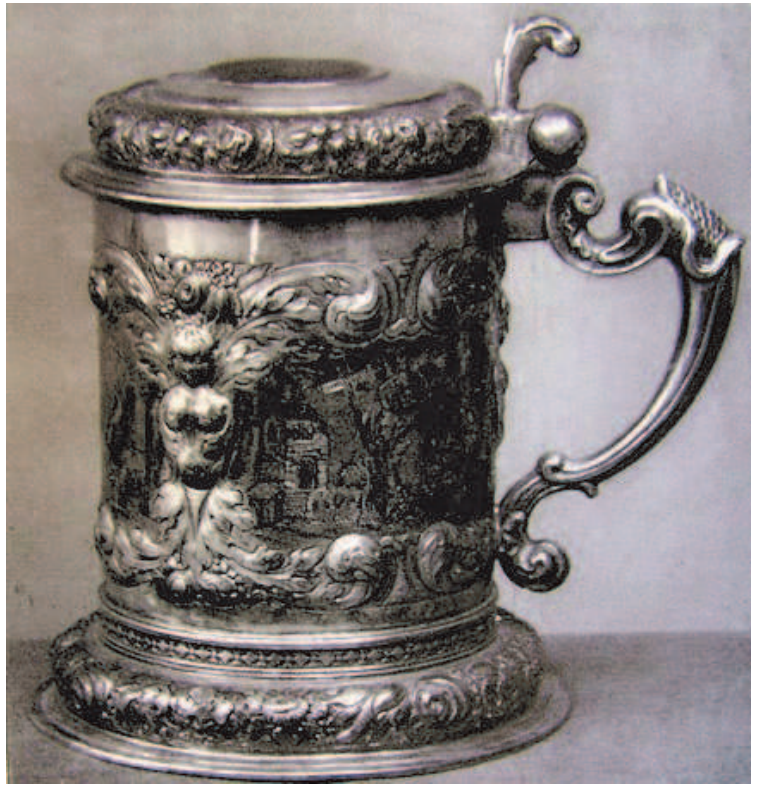

Il. 8. Johann Christian Bröllmann, kufel, 1700-1719 r. (fot. za: Altes Kunstgewerbe, Glas, Keramik, Metallarbeiten, alte Gemälde und Skulpturen, Ostasiatica, Teppiche aus Hochfürstlichem Besitz sowie aus Reinischem Privatbesitz und anderem $\mathrm{Be}$ sitz. Versteigerung in der Galerie Hugo Helbing München, 4-5 April 1930, München 1930, s. 13, kat. 150, il. Tab. III.)

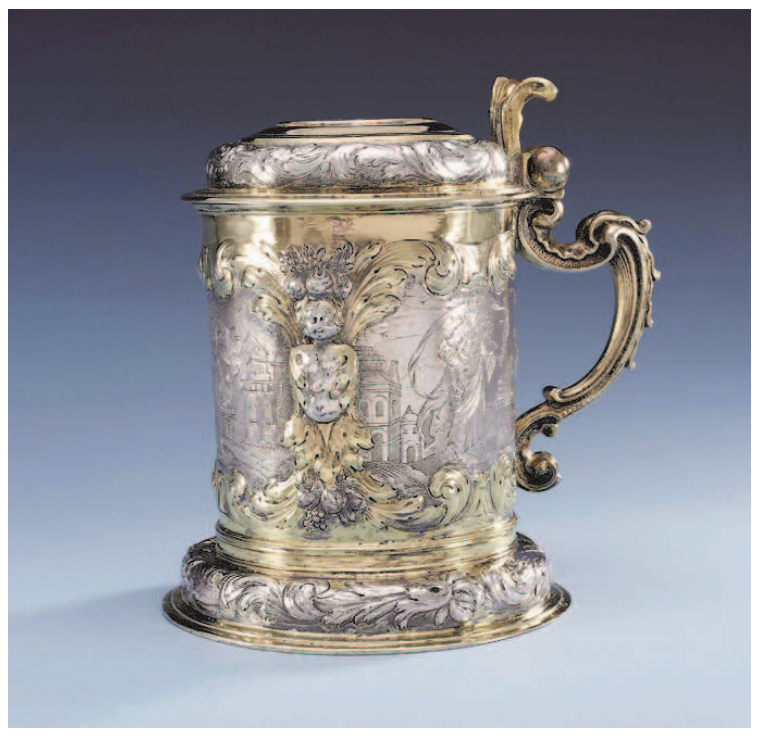

Il. 8a. Stefan Petersen, kufel, ok. 1690 r., (fot. za: Bukowskis Internationella Auction Hosten 2004, Auktion No. 534) 

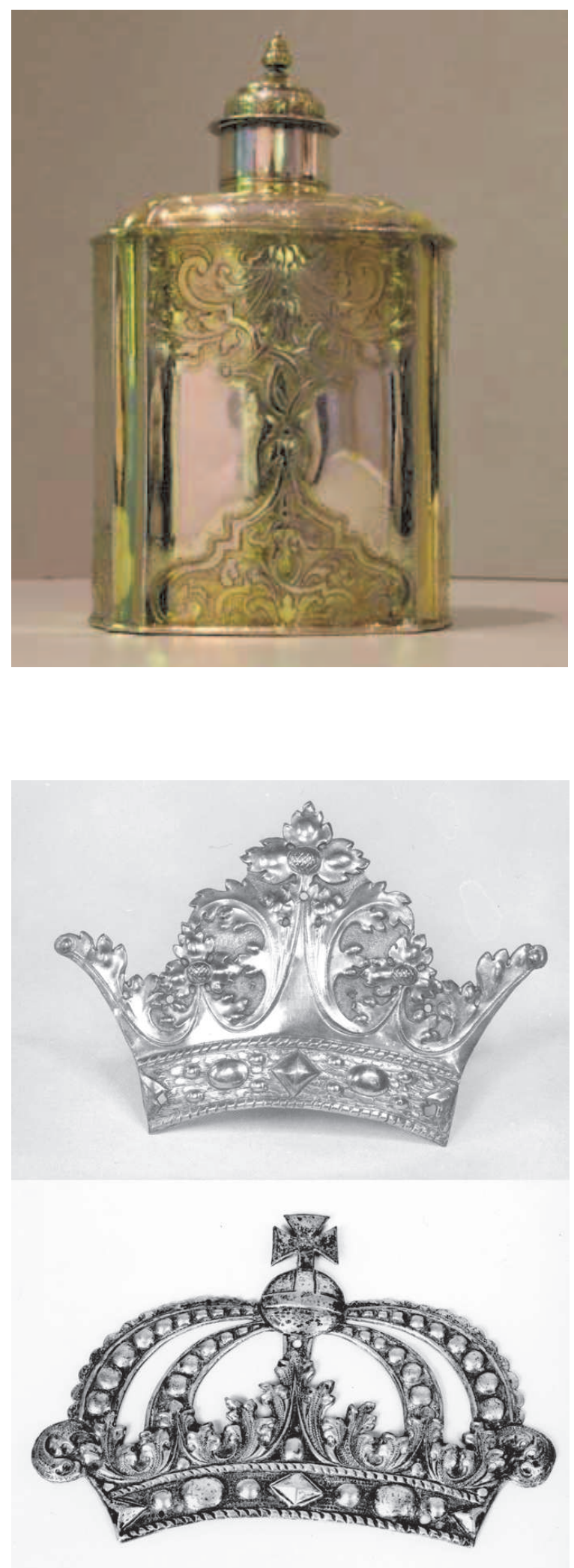

Il. 9. Johann Christian Bröllmann, puszka na susz herbaciany, ok. 1720 r., Westpreußisches Landesmuseum, Münster-Wolbeck (fot. A. Frąckowska)

Il. 10a-b. Johann Christian Bröllmann, korona, fragment aplikacji, ok. 1720 r., Muzeum Okręgowe w Toruniu (fot. Muzeum Okręgowe w Toruniu, Wacław Górski); korona wotywna, Święcieniec, kościół par. pw. św. Anastazego i Wincentego (dokumentacja złotnictwa IZK, fot. W. Górski) 

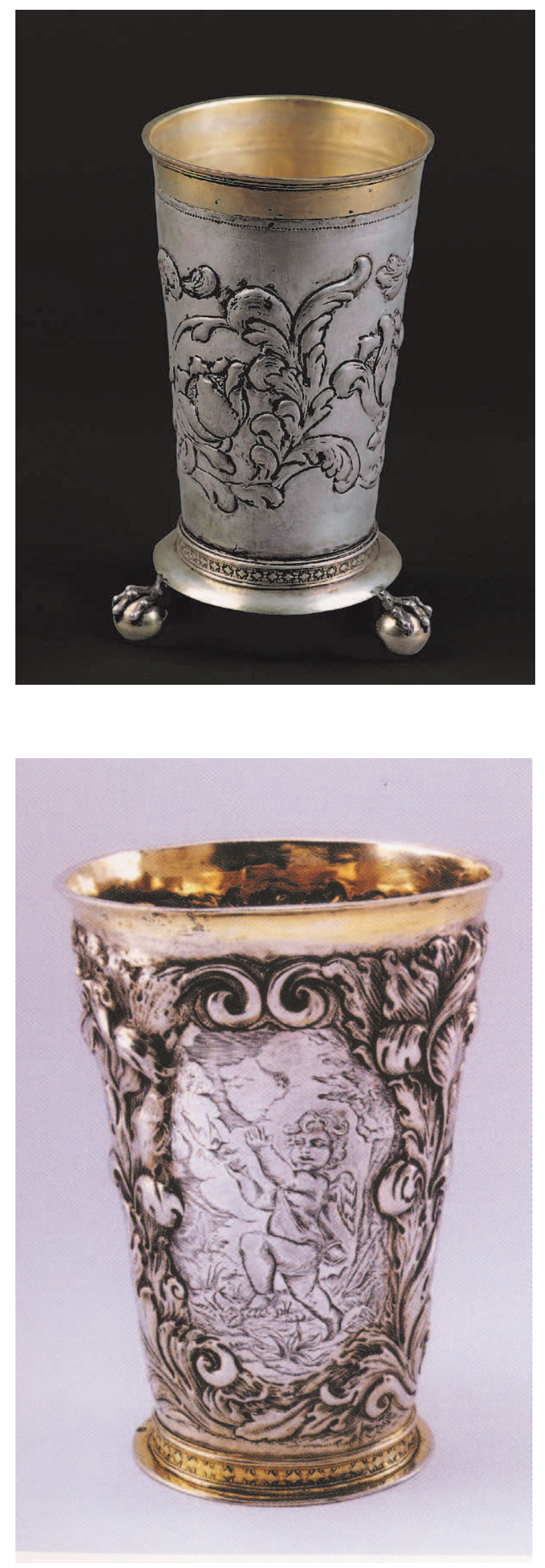

11. Johann Christian Bröllmann, kubek, ok. 1710 r. (fot. za: http:// www.agraart.pl/cgi-bin/obiekt. cgi? act $=1 \& q \mathrm{t}=1221841766 \& \mathrm{nr}=68$ 96; 10.04.2009)

12. Johann Christian Bröllmann, kubek, 1719 r., (fot. za: Klejnot w Koronie Rzeczypospolitej. Sztuka zdobnicza Prus Królewskich. Katalog wystawy Muzeum Narodowego w Gdańsku, red. Cz. Betlejewska, Gdańsk 2006, t. II, Katalog, s. 211, kat. III.53) 




Il. 13. Niklaus Bröllmann, kubek, dawniej Gdańsk Provinzial-Muzeum (fot. za: Straty wojenne Muzeum Miejskiego i Muzeum Rzemiosła Artystycznego w Gdańsku, t. II: Straty $w$ dziedzinie rzemiosła artystycznego: meble, bursztyn, metale, red. I. Ziętkiewicz, Gdańsk 2005, s. 75-170 , poz. 74 , s. 99 .) 


\section{Summary}

\section{The Bröllmanns - Torun silversmiths from the turn of $17^{\text {th }}$ century. Addenda et corrigenda}

The paper constitutes an annex to the text by Jacek Tylicki, published in this journal in two parts (1992 and 1994). It completes biographical data on the Bröllmanns, revises some former attributions and presents recently discovered objects made in their workshops.

Newer archival research disclosed that the second wife of Niklaus and mother of both Johann Christian and Samuel was Anna Chodowiecka, related to the somewhat younger renowned draughtsman and engraver from Gdańsk, Daniel Chodowiecki. Exact life dates of her both sons are now known; it is also possible to pinpoint the dwellings of all the members of the family on the town map. Niklaus and Johann Christian have been members of the town's authorities (within the 'Third Order'), and the latter also held the elder's post in the local Calvinist religious commune. Johann Christian was married to Elisabeth Hemling, and had two sons with her, none of which continued, however, their father's profession. The younger son of Niklaus, Samuel, probably did not erect his own workshop, collaborating with his brother.

Eighteen further objects have now been found, which originated with certainty from the workshops of both silversmiths. Among them, Niklaus produced two chalices, one paten and an altar lamp typical in form and decoration; furthermore, interesting and scarce lay objects by this master have surfaced: a beaker, a tazza with floral decoration, another sizeable tazza inset with coins as well as a coin tankard and a doctoral thesis. All of them confirm the known abilities of the craftsman, displaying high technical and artistic quality, as well as his knowledge of most up-to-date stylistic trends, visible in decoration.

The newly identified part of Johann Christian's oeuvre comprises a chalice, a devotional painting application in form of a crown, a pair of candlesticks, three beakers and a spoon - objects typical both for formerly known production of the master, and of the Torun milieu in gene- 
ral. There appeared, however, also two others, much more worthwhile: an imposing tankard decorated with personifications of virtues in high quality repoussé technique, and a tea box (unique in Torun silversmith) with régence ornament. In its diversity, Johann Christian's work shows similarity to the production of such celebrated local masters as Johann Christian Bierpfaff, Jakob Sachs, or Stephan Petersen, and in singular cases his products resemble the ones from their ateliers. As it has already been pointed out before, however, it represents - in contrast to the aforementioned masters - a very uneven level of craftsmanship both in technical and purely artistic terms: while the craftsman was rather at ease executing the repoussé parts, he apparently could not adequately cope with the engravings.

The recently found objects by both masters are especially worth attention as far as those of lay character are concerned, since such items are relatively rare in Torun silverware production. Equally important is that in numerous cases their history and persons of commissioners are well known. 